\title{
KARST AND CAVES IN SALT DIAPIRS, SE ZAGROS MTS. (IRAN)
}

\section{KRAS IN JAME V SOLNIH DIAPIRJIH JUGOVZHODNEGA ZAGROSA (IRAN)}

PAVEL BOSÁK ${ }^{1} \&$ JIŘÍ BRUTHANS ${ }^{2}$ \& MICHAL FILIPPI ${ }^{3}$ \& TOMÁŠ SVOBODA ${ }^{4} \&$ JAKUB ŠMIID 5

${ }^{1}$ Institute of Geology, Academy of Sciences of the Czech Republic, Rozvojová 135, CZ-165 02 PRAHA 2, CZECH REPUBLIC, e-mail: bosak@gli.cas.cz

2 Betlémská 10, CZ-110 00 PRAHA 1, CZECH REPUBLIC

${ }^{3}$ SNP 2008, CZ-440 01 LOUNY, CZECH REPUBLIC

${ }^{4}$ Částkova 12, CZ-301 57 PLZEÒ, CZECH REPUBLIC

${ }^{5}$ CZ-273 04 KAČICE 79, CZECH REPUBLIK, e-mail: smid@ natur.cuni.cz 
UDK: 551.44(55)

\section{Pavel Bosák \& Jiř́ Bruthans \& Michal Filippi \& Tomáš Svoboda \& Jakub Šmíd: Kras in jame v solnih} diapirjih jugovzhodnega Zagrosa (Iran)

Na področju Perzijskega zaliva je znanih okoli 200 solnih diapirjev, med njimi mnogo aktivnih. Kraške kamnine predstavljajo največ kamena sol in redkeje sadra ter anhidrid. Kraške oblike, popolnoma primerljive z oblikami v "klasičnih" karbonatnih kamninah, so najbolje razvite v ostankih uravnanih površij. Tako so škraplje, "solution pipes", vrtače, udorne vrtače, depresije podobne uvalam in poljem, slepe doline, soteske, ponori, izviri in jame. Tod sta bili odkriti in raziskani dve izmed najdaljših jam v soli na svetu. Daljše jame so nastale predvsem v piezometrični gladini, večje pa v diapirjih ob morski obali. Jame pogosto predstavljajo odtok iz depresij, podobnih poljem. V dnu udornih vrtač in v ponorih so tudi strme, skoraj navpične jame. Kraški procesi so omejeni predvsem na sol, redkeje na sadro. Predvsem gre za raztapljanje in odnašanje soli izpod neprepustnega pokrova (gypcrete). V nekaterih diapirjih je dokazano globoko kroženje padavinske vode.

Ključne besede: kras, jama, solni diapir, speleogeneza, jugovzhodni Zagros, Iran.

\section{Abstract}

UDC: $551.44(55)$

\section{Pavel Bosák \& Jiří Bruthans \& Michal Filippi \& Tomáš Svoboda \& Jakub Šmíd: Karst and caves in salt diapirs, SE Zagros Mts. (Iran)}

About 200 salt diapirs (plugs) have been known in the region of the Persian Gulf. numerous are still active. Karst rocks are represented by a rock salt, less frequently by gypsum and anhydrite. Karst developed especially in relics of planated surfaces. Karst forms are completely comparable with karsts in classical carbonate rocks. Different forms can be distinguished: karren, solution pipes, solution dolines, solution-collapse dolines, uvalalike to polje-like depressions, blind valleys, canyon-like forms, ponors, springs and caves. Two World longest caves in salt were discovered and explored here. Long caves are developed especially in a watertable, large ones in plugs near the seacoast. Caves are often outlets of closed depressions (polje-like). Some caves at bottoms of collapse-solution dolines or swallow holes are subvertical. Karst processes are caused dominantly by dissolution of salt, less frequently of gypsum. The process of subrosion of halite under gypcretes plays the main role. Deep circulation of meteoric waters was proved in some plugs.

Key words: karst, cave, salt plug, speleogenesis, SE Zagros Mts., Iran. 


\section{INTRODUCTION}

Salt plugs (diapirs) of the south-eastern part of the Zagros Mts. have been subjects of interest since the $17^{\text {th }}$ Century (Tavernier 1642). Nevertheless, karst features have been studied only rarely. Some notes concerning karst can be found only in contributions of Harrison (1930), Fürst (1970, 1976), Bosák (1993) and Bosák et al. (1998, 1999).

Preliminary data on karst features in plugs were obtained during geological and hydrogeological expeditions in 1988 ( $c f$. Bosák 1993) and in 1992 to 1993 ( $c f$. Bosák et al. 1998) organised by the former geological exploration company of Geoindustria Praha. Some cave entrances in the Hormoz, Khamir and Namakdan salt plugs were located. During detailed helicopter reconnaissance in 1992 and 1993, karst forms in plugs visible from air were surveyed, and air photos were evaluated in detail (Bosák et al. 1998). Speleological expeditions were organised in summer of 1997, February to March 1998, and January to February 1999. Salt plugs with already known karst forms and caves and plugs with highly promising natural conditions were explored. Plugs were selected according to criteria mentioned in Bosák et al. (1998). Explorations were carried out in the Hormoz Island (Hormoz plug, No. 1 in Fig. 1) and in the Qeshm Island (Namakdan plug, No. 4). Kuh-e-Namak north of Bandar Abbas was shortly visited, too (Khurgu plug, No. 27). The following members, students of geology at Charles University in Praha, took part in expeditions: Jiří Bruthans (1997, 1998, 1999), Michal Filippi (1998,1999), Lukáš Palatinus (1999), Tomáš Svoboda (1998, 1999), Jakub Šmíd (1998, 1999), and Michal Vašíček (1998).

\section{MORPHOLOGY}

The studied area lies in the southern part of the Islamic Republic of Iran near the northern shore of Khalij-e Fars (Persian Gulf). The south-eastern part of the area shown in Figure 1 belongs to the Hormozgan Province and the north-western part of the area lies in the Fars Province. The area belongs to the eastern part of the Zagros Mountain Range and the Persian Gulf Platform. Khalij-e Fars is a shallow epicontinental sea. Jazireh-ye Qeshm is the largest near-shore island near the coast. The smaller offshore islands (Hormoz, Larak, Hengam, etc.) are salt plugs, partly fringed by the recent or subrecent coral reefs and marine terraces.

The continental region can be classified as hilly to mountainous. In general, the W-E trending anticlinal mountain ridges and synclinal valleys are the most distinct morphological elements. The synclinal depressions show variable morphology. For the dominant amount of valleys is typical the flat bottom (U-shaped valleys) filled with young alluvial sediments deposited in meandering to braided river systems. Others are deep, canyon-like or V-shaped valleys. Deep antecedent valleys, common in higher zones of the Zagros Mountains (Oberländer 1965) are relatively rare. Telescoping alluvial fans often contours foots of ranges.

The relief is very young; the principal folding is only of middle Pliocene to Pleistocene in age, and the movement has been continuing up to the present time with relatively high intensity. VitaFinzi (1979) calculated $1.9 \mathrm{~mm}$ of annual uplift in Gachin and Qeshm areas.

Planation surfaces are developed only at a small scale. Both river and marine terrace systems (Fürst 1970) document the cyclic uplift of the region and the sea level changes. Relics of abrasion and/or accumulation marine terraces are visible along the present coast and on some of the small 
islands in the Persian Gulf. The best example of coastal terrace is developed between Puhal and Lashtegan, comparable with the abrasion terrace at +15 m on Jazireh-ye Hormoz ( $c f$. Gansser 1960). Higher terraces at +25 to +30 m a.s.l. occur also on Jazireh-ye Hormoz, and Quaternary conglomerate and beach sand can be found even as high as at $+100 \mathrm{~m}$ a.s.l. in islands and on some of coastal plugs (Gansser 1960; Bosák et al. 1998). This provides evidence for young vertical movements of the area and an uplift of salt plugs ( $c f$. Kent 1958) in this region.

The salt plugs of this region have a special morphology, forming highly positive forms or negative forms of relief, reflecting the plug activity.

\section{GEOLOGY}

The Zagros Fold Belt of the Zagros system is composed of elongated whaleback or box-shaped anticlinal mountains. The structures generally trend in the NW-SE direction. Besides gently dipping overthrusts, folds are dissected also by subvertical normal and wrench faults. The Zagros fold system is overthrusted along and cut off by the Zandan Thrust, a branch of the Zagros Main Thrust, approximately $75 \mathrm{~km}$ east of Bandar Abbas.

\begin{tabular}{|c|c|c|c|c|}
\hline \multicolumn{5}{|c|}{$\begin{array}{c}\text { APPENDIX } \\
\text { Numbers and names of salt plugs (see Fig. 1) }\end{array}$} \\
\hline 1 & Hormoz & 23 Chahar Birkeh & 46 & Pashkand \\
\hline 2 & Larak & 24 Gezeh & 47 & Khain \\
\hline 3 & Hengam & 25 Khemeshk & 48 & Darmandan \\
\hline 4 & Namakdan & 26 Takhu & 49 & Aliabad \\
\hline 5 & Berkeh-ye Suflin & 27 Khurgu & 50 & Tang-e Zagh \\
\hline 6 & Band-e Muallem & 28 Genow & 51 & Palangu \\
\hline 7 & Bustaneh & 29 Gurdu Siah & 52 & Mesijune \\
\hline 8 & Moghuieh & $30 \mathrm{Shu}$ & 53 & Kurdeh \\
\hline 9 & Chiru & 31 Bam & 54 & Deh Kuyeh \\
\hline & Gachin & 32 Zangard & 55 & Nina \\
\hline & Puhal & 33 Pordelavar & 56 & Namaki \\
\hline & Khamir & 34 Gavbast & 57 & Sarmand \\
\hline & Mijun & 35 Bongod-e Ahmadi & 58 & Gahkum-East \\
\hline & Do-Au & 36 Kajagh & 59 & Saadat Abad \\
\hline & Zendan & 37 Finu & 60 & Gahkum \\
\hline 16 & Champeh & 38 Ardan & 61 & Muran \\
\hline & Chah Musallem & 39 Tarbu & 62 & Qaleh Shur \\
\hline & Charak & 40 Tashkend & 63 & Goru \\
\hline & Genah & 41 Shamilu & 64 & Bana Kuh \\
\hline 20 & Qalat-e Bala & 42 Chah Banu & 65 & Bonaruyeh \\
\hline & Anguru & 43 Chahal & 66 & Jalalabad \\
\hline & Ilchen & 44 Siah Tagh & 67 & Kush Kuh-West \\
\hline & & 45 Gach & 68 & Darbast \\
\hline
\end{tabular}




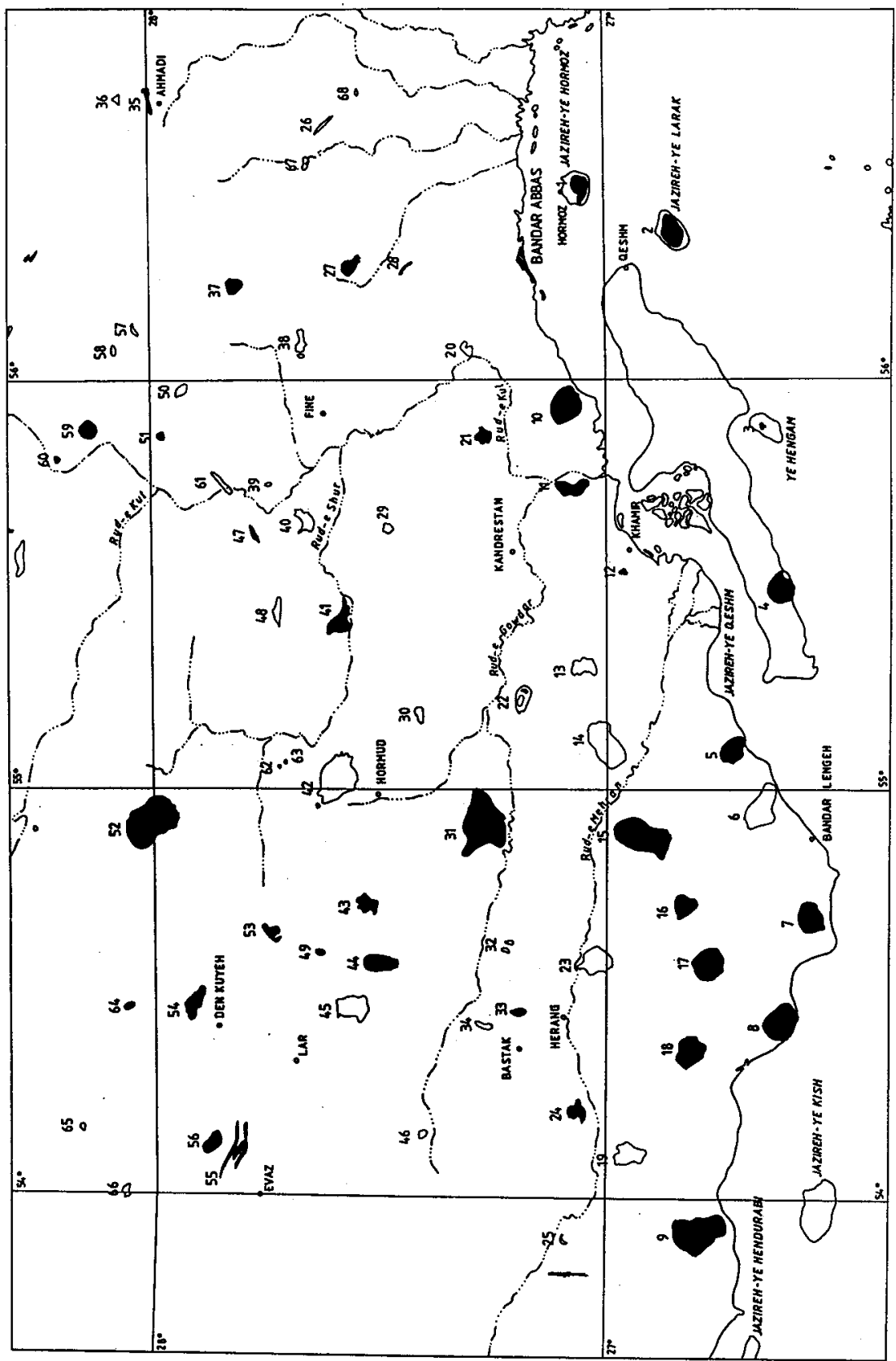

Fig. 1: Study area and the distribution of salt plugs. Salt plugs with detected karst forms are in black (for names of plugs see the Appendix; courtesy of the Institute of Geology, Academy of Sciences of the Czech Republic, Praha). 
Plugs occur mostly in anticlinal structures, at their termination (plunge), in sigmoidal bends of fold axes (circular plugs; Fürst 1976). The position within anticlines is mostly located on flanks, not in the axial part. Only several salt bodies are situated closer to the syncline axis. Salt glaciers moving from plug positions downslope have logically synclinal position, in places. Salt plugs partly occur in straight portions of anticlines, but a majority of them is located in places of sudden bends or horizontal displacements of anticline axes even if the position in "knots" on anticline axes is not the rule.

\section{SALT PLUGS}

About 200 salt plugs (Kent 1970) have been known in the area of the Persian Gulf. Salt plugs (diapirs, domes) are still morphodynamically active (e.g., Fürst 1970; Talbot and Jarvis 1984). They have different diameters, and a conical shape with clear evidence of mushrooming near the surface (Kent 1958). They contain "exotic blocks" with diameters up to $2 \mathrm{~km}$.

The size of salt plugs usually varies between about 1 and $15 \mathrm{~km}$ (along longer axis). The maximum size is $17 \mathrm{~km}$. Two size groups of salt plugs were distinguished: (1) small, and (2) large ones (Bosák et al. 1998). According to the shape, salt plugs proper (without glaciers) can be subdivided into: (1) circular, (2) linear, and (3) combined principle types (Bosák et al. 1998).

Salt plugs according to the activity can be distinguished to: (1) active, (2) passive, (3) ruins of plugs, and (4) unbreached plugs (Fürst 1970, 1976; Bosák et al. 1998). Some authors estimated the morphological uplift of active plugs from 2 to 4 inches $(3$ to $6 \mathrm{~cm}$ ). Trusheim (1960) reported annual accretion of 1 to $2 \mathrm{~mm}$. Talbot and Jarvis (1984) proved a high rate of salt extrusion at an estimated average rate of about $2,000 \mathrm{~mm} \cdot \mathrm{a}^{-1}$ at the head of plugs with more active glacier. Still active Zagros folding and pressurisation cause the intrusion. Comparison of air photos of Chahal plug (No. 43) and the recent situation in the field proved the larger extent of glaciers than visible on 35 years old photos ( $c f$. Bosák et al. 1998). The criterion of activity highly influences the occurrence and density of karst forms in plugs; therefore the principal characteristics of plugs according to their activity are given here.

\section{Active plugs}

Active plugs (group No. 1) have positive relief, periclinal stream network, and dominant role of evaporites and minor karst collapse structures. The character of morphological forms, degree of stream network entrenchment, amount of evaporites outcropping on the surface and intensity of karstification were detailed for further subdivision into subgroups.

Subgroup 1a: expressive morphology (cupola, dome, whale back), high height differences of plug foothills and the summit part, extremely steep slopes, often slightly vaulted summit plateau which is sometimes pointed up by the central summit, minimum detailed dissection, predominance of evaporites, other rock types occur in blocks enclosed by evaporites, fissures system is developed, often breakoff planes with collapsed material, which can represents initiations of glacier flows in suitable places, large karst forms are practically missing, nevertheless smaller forms can be numerous.

Subgroup 1b: distinct morphology with lower total height differences, mostly with steep slopes, vaulted summit plateau, low dissected plug surface, locally developed areal drainage of summit part, periclinal drainage is initiated at sides which represent the change of integrated plug shape, 
major parts of plugs is formed by salt, debris of clastic sediments and igneous rock occur on plug margins, glacier flows are locally developed, larger karstic forms are developed in places, relatively abundant karst forms.

Subgroup 1c: positive morphology, often dissected into several segments with different morphologies, distinctly rugged morphology within some segments, expressive centre in large plugs in which evaporites are largely present on the surface, blocks of other Hormoz lithologies occur more substantially at margins, large salt glaciers are usually developed on small plugs, common periclinal drainage, sometimes combined with other type (circular, dendritic), expressive karstification of rock salt.

\section{Passive plugs}

Only small occurrence of salt on the surface, which amount gradually decreases as plug is degraded is typical feature of passive plugs (group No. 2). The portion of gypsum relatively increases. In suitable morphological conditions, collapse structure develops in more and more developed stage (variability both of plug morphology and of encircling cauldron). The abundance of karst forms is also variable depending on proportion of evaporites and other rock at near-surface level and plug morphology. Different types of drainage network can be observed.

Subgroup 2a: still distinct morphology (copula, dome), presence of summit plateau or other types of planated (levelled) surfaces, relatively steep slopes, lesser dissection of plug surface, but with deeply entrenched V-shaped valleys (unopposed gradient with large height differences over a short distance), usual periclinal net of intermittent streams, salt outcrops in marginal parts and at bottom of deep entrenchments, surface covered by other Hormoz lithologies, still slightly developed cauldron, expressive karst in salt.

Subgroup $2 b$ : preserved copula-like or domed shape but with highly rugged relief both in the plug centre and at margins, locally preserved summit plateau or other planated (levelled) surfaces on larger plugs which are commonly destructed on smaller ones, combination of periclinal drainage network and other types (circular and centriclinal), karst forms occur in still in large amounts, especially in marginal zones where salt can still occur.

Subgroup 2c: domed shape is preserved only at margins, the central part is highly eroded, summit plateau is missing, other types of planated (levelled) surfaces can occur, soft morphology is developed in some plugs, valleys are predominantly of U-shape type, periclinal net of intermittent streams is not frequent, other types predominate in combinations (dendritic, parallel, circular), karst forms are usually less abundant then in other categories of passive plugs, or are destroyed, halite is normally lacking.

\section{Ruins of salt plugs}

The diapirism has ceased long ago in general; although limited areas of some subgroups can still show limited uplift of evaporitic rocks (group No. 3). Generally negative morphology is typical if cauldron is developed. Indistinct morphology characterises plugs without cauldron. Soft morphology of relics of the Hormoz material is built of rounded hills protruding through Recent and subrecent sediments (deluvia, alluvia, marine deposits etc.). Relics of the Hormoz material often occur on cauldron slopes as several meters thick layers owing to high alteration and ferruginisation. The dendritic network of intermittent streams prevails in a combination with other drainage types. Centriclinal drainage emptying into linear (parallel) network can occur. Halite was 
mostly leached away; its occurrence in deeper parts of plugs cannot be excluded. There were distinguished three subgroups of ruins, nevertheless the criteria are not strict. Karst forms are therefore generally missing, except smaller parts with still active diapirism or parts where diapirism ceased not so long ago.

\section{Glaciers of salt plugs}

Salt glaciers are one of the most striking phenomena which have interested geologists since the beginning of plug investigation. Lees (1927) who introduced the term salt glacier into the literature gave first evaluations. Talbot and Jarvis (1984) proposed the term „namakier” which name is composed of Farsi name for salt -namak- and glacier. We are using here the traditional term salt glacier (glacier flow, glacier tongue). Salt glaciers can be distinguished into (Trusheim 1974): (1) hanging glaciers (on slopes of anticlines), and (2) tongue-like to extensive foothill glaciers intervening synclines.

The conditions of their origin have been compared with the origin of true ice glaciers. The occurrence of salt glaciers is influenced by numerous geological factors; nevertheless the temperature and precipitation on the surface are very important factors widely influencing the viscosity of intruded material. Glaciers show the tight connection to small plugs, eventually to combined or linear plugs. Typical feature of such plugs is a narrow vent during which Hormoz material is ascending. Karst forms occur within salt glaciers relatively frequently; even small caves can be observed.

\section{KARST ROCKS}

Karst rocks in which karst forms are developed belong to the Hormoz Complex, the main constituent of salt plugs and to its alteration products.

The Hormoz Complex was deposited during Upper Precambrian (Riphean-Vendian) to Middle Cambrian age on rifted continental margins of Arabian Plate in rectangular basin limited by deep (crustal) faults. The Hormoz Complex represents product of deposition in evaporitic basin with multi-cyclic nature and repeating horizons of salts and other evaporites within carbonate-clasticvolcanosedimentary levels. The percentage and thickness of gypsum and especially of salt decreased from the centre of the basin towards its margins. The deposition of sediments was highly influenced by projected structural zones of the basement. Predominance of acid volcanics and volcanoclastics is bound to the southeastern part of the region close to the Oman line (Bosák et al. 1998).

\section{Salt}

Rock salt (halite) is a basic constituent of many plugs, mostly active ones. Impurities of nonevaporitic material are expressed in multicoloured lamination and banding. Salt is white, greenish white to grey, red, purple, brown, green. Without impurities, the colour is light green, sometimes orange, yellow, light red. Impurities are represented by finely dispersed mineral and rock particles, or they are accumulated in tiny laminae or bands and/or as smaller or larger rock fragments to blocks. Sedimentary rocks and volcanoclastics contained in salt represent, at least partly, broken primary intercalations. Salt contains interbeds of layered gypsum with dark dolostones, dark foetid crystalline gypsum with ferruginous bands, and sandstones, siltstones, tuffitic rocks and carbonates. In some places, accumulations of rock debris resemble fossil scree falling into a salt depositional 
basin or transported by superficial weathering products. The proportion of salt in individual plugs depends on the primary content of salt beds within the Hormoz depositional basin. Salt is often highly folded up to enterolithic structures due to diapirism. Rock mechanic (halokinetic) properties of salt and salt buoyancy under pressure caused the diapir ascend. On some places, salt is recrystallised into large, up to decimetric crystals. The recrystallisation is supposed to be young, Recent to subrecent process (e.g., Kent 1979). Besides halite, other salts also were reported in limited amounts ( $c f$. Fürst 1976).

\section{Gypsum and anhydrite}

All occurrences of gypsum in plugs are derived from primary gypsum sequences of the Hormoz Complex, which were deformed, folded and squeezed during diapirism. In the Saadat Abad plug, layered, banded to laminated and disharmonically folded primary gypsum sequence reaches up to $100 \mathrm{~m}$ in thickness, indicating an approximate possible thickness of primary gypsum strata within the Hormoz Complex. The percentage of gypsum in the plug composition increases with the higher degree of plug ruination as the salt is dissolved at the surface. Gypsum forms usually matrix of "exotic" blocks, which is usually multicoloured, white, pink, red, purple, green, grey, brown, black, etc. It contains fragments of different kinds of rocks. It is highly tectonised and disharmonically folded, in places (Bosák et al. 1998). In many plugs, gypsum constitutes the basic evaporitic material in the form of gypsum breccias containing abundant clasts of other lithologies. At plug margins, gypsum is a basic component of hematitised rim zone. Sometimes, different lithologies form thin interbeds in gypsum, indicating that gypsum among blocks partly conserves its primary sedimentary structures.

Anhydrite occurs in frequently and, owing to its instability in near-surface conditions, its occurrence is restricted but not completely excluded. It is mostly white, hydrated and altered on block surfaces into white to green gypsum of sandy appearance (Bosák et al. 1998).

Karst in gypsum and anhydrite, except of very small forms (karren), was not detected on plug surfaces.

\section{Cap rock and brownish gypcrete}

Cap rock constitutes the uppermost part of many salt plugs, especially when the top of plugs is covered. Its absence can be ascribed to the fracturing, dissolution and collapse of diapiric summits (Jenyon 1986). Owing to surface outcrops of plugs within the studied area, sequences, which can represent typical cap rock, are only scarce. Cap rock is composed of layered laminated gypsum with intercalations of iron-rich material and high degree of cementation. Sulphur occurrences are typical for some cap rocks (Pilgrim 1908). Brownish gypcretes of sandy appearance can result from the near-surface and surficial alteration of cap rock.

The surface of numerous plugs, without any respect to the activity degree, is covered by brownish gypcrete of variable thickness from about 3 to $10 \mathrm{~m}$, sometimes more. The term was introduced by Bosák et al. (1998) for gypcretes with sandy appearance and variable degree of induration. The admixture of clastic quartz is variable and represents eolian material, most probably. In detail, the crust is sometimes laminated by reddish hematite accumulations, sometimes it is carbonatised, in individual cases it passes upwards into limonitised beds. In some plugs it contains dark pigment and the structure resembles pedogenic horizons. Sometimes the crust contains even gravel material. Both in the Hormoz and Namakdan salt plugs, brownish gypcrete shows traces of lamination or 
bedding, resulting from short distance reworking. In active plugs, the gypcrete covers the summit plateaus and flat surfaces originated by the dissection and uplift of original summit flat surfaces. The origin of the brownish sandy gypcrete can be connected with (1) the certain degree of the stabilisation of plug uplift, and (2) weathering and dissolution of plug material, where it was formed also by the hydratation of anhydrite. Lamination can indicate short redeposition of the material before it is more or less cemented. The dissection of crusts on present plug surfaces proves young renewal of diapirism in some plugs. Erosion of less active to inactive plugs damaged the crust into relics.

\section{KARST FORMS}

Karst forms in salt and other evaporites of the studied region are nearly identical with karst forms developed in a classical karst rock - in limestones.

Karren. Sharp rillenkarren developed in rock salt predominate. Pinnacles comparable with tropical mega-karren in limestones are less abundant. Vertical towers (columns) develop often along margins of salt. They resemble residual hills and towers in carbonate rocks originated by lateral corrosion (karst pedimentation). They occur in salt and brownish gypcrete.

Solution pipes are very common forms. The are vertical, cylindric, with diameter up to several meters and a depth of even several tens of meters. They are developed dominantly in rock salt.

Solution dolines are ovate or asymmetric and dominantly funnel-shaped. Their diameters vary between several meters up to more than $100 \mathrm{~m}$. Their diameter is larger in brownish gypcrete. In some cases, dolines cover a substantial part of the plug surfaces as doline fields. Vertical solution pipes to shafts or inclines swallow holes are often developed in doline bottom.

Solution-collapse dolines are ovate, elongated, or irregular with common diameters of 20-30 m, sometimes less or more, and with the depth even more than $45 \mathrm{~m}$. Walls are subvertical and sculptured. Lakes at bottom resembling ,cenotes” can be developed in places (e.g. on Chiru plug, No. 9, with bottom at $-37 \mathrm{~m}$ b.s.l.). Forms are developed in gypcrete underlain by rock salt. Their origin due to subrosion of salt below brownish gypcrete in phreatic and vadose conditions, but most commonly at the groundwater level cause the separation of this special type. The initial stages of the process are not visible on the surface as the gypcrete still forms a thin crust owing to the small size of the corroded space. The enhanced corrosion leads to collapse of the gypcrete. The opening with diameter of fiew meters appeared. The space below the gypcrete is increasing downwards. Bottom is often covered by a conical heap of collapsed material. Continuing process leads to large forms.

Uvala-like depressions have usually elliptic shape and they are formed by coalescing dolines. Their diameter is in hundreds of meters and the depth in tens of meters. The forms are mostly connected with huge underground streams contributing to erosion of clastic material and gypcrete. Lateral corrosion plays a role in some places.

Polje-like depressions characterised by a flat bottom and numerous ponors represent special form of blind valleys, in most cases, i.e. some sort of semi-poljes and/or border poljes. Only rarely, karst springs and ponors occur in the same depression. Flat bottom is mostly due to accumulation of sediments (detected thickness over $50 \mathrm{~m}$ ), in a lesser extend due to lateral corrosion and erosion at the surface of sediments (karst pedimentation). 


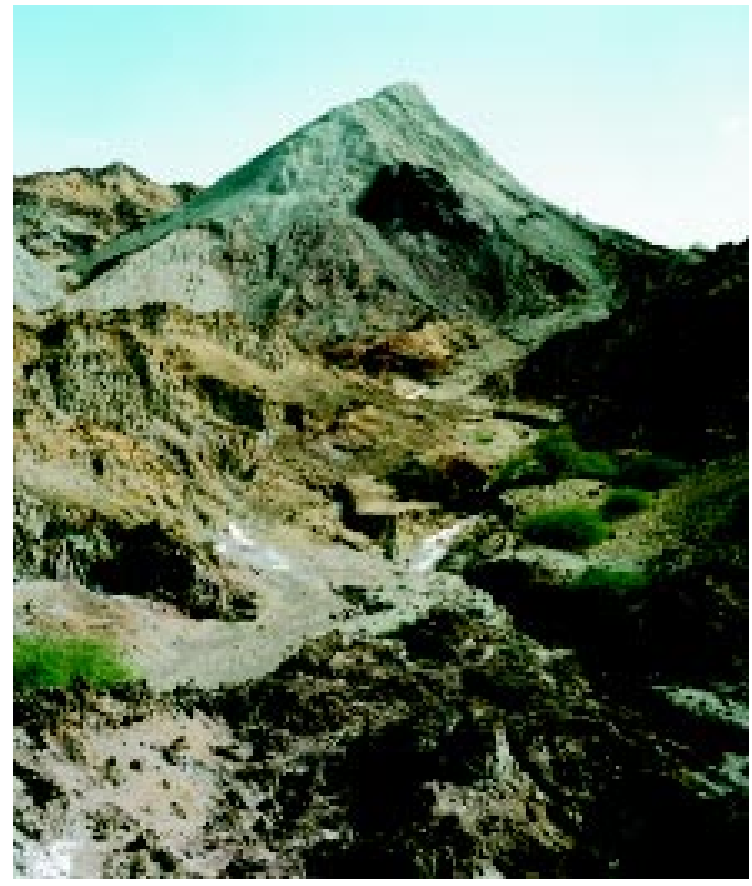

Photo 1: Hormoz plug. Blind valley with the Portal Cave (H9). Hill in the background is made of a large exotic block (rhyolite) of the Hormoz Formation.

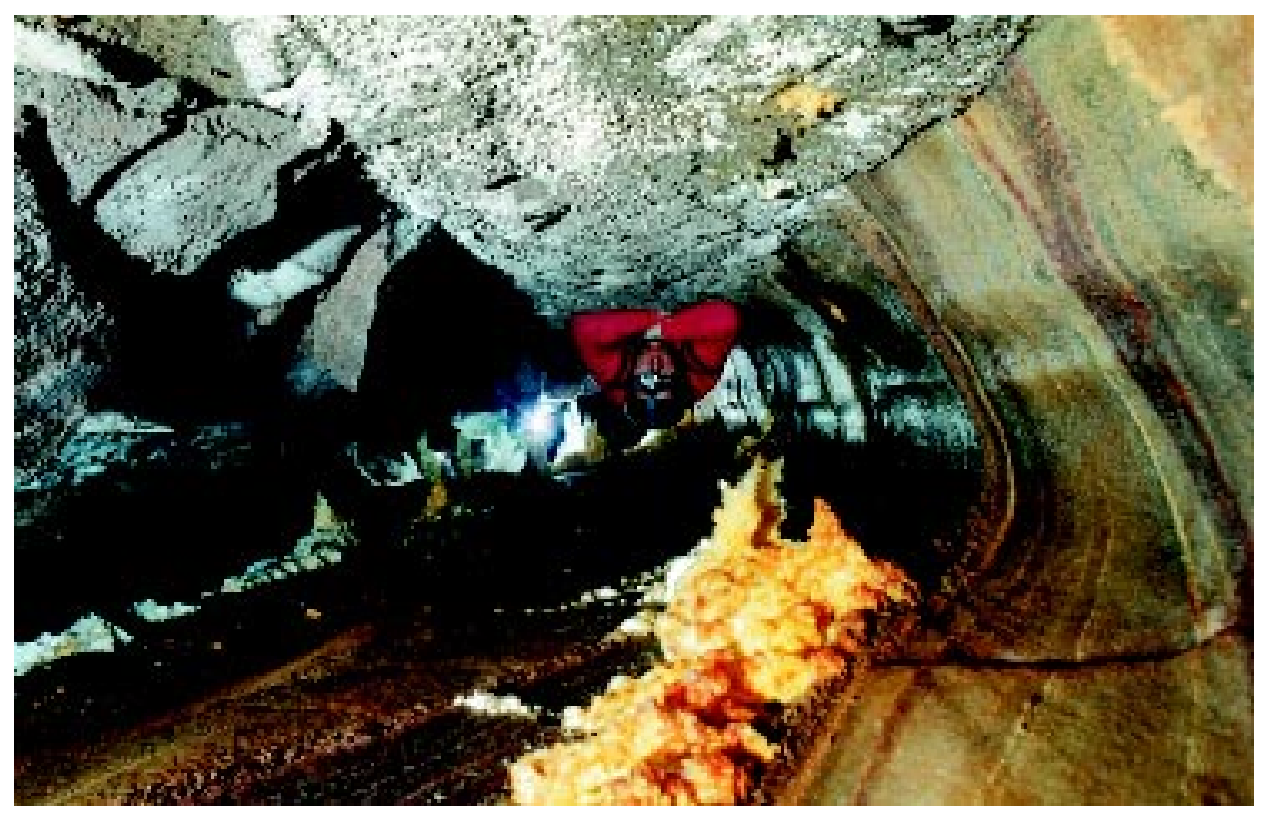

Photo 2: Ghár-e Daneshyu Cave (H8, Hormoz plug). Wall niche and flat roof in steeply inclined rocky salt. 


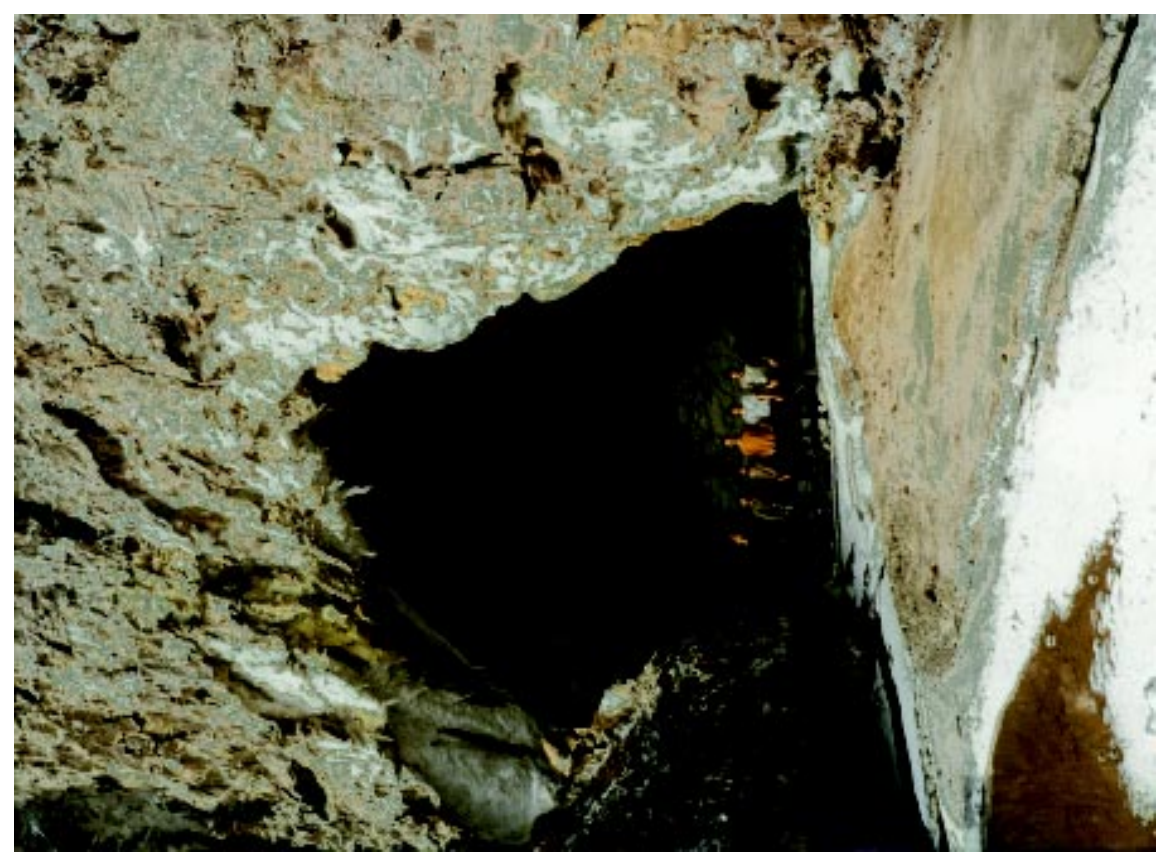

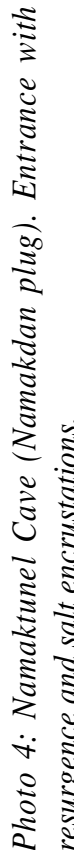

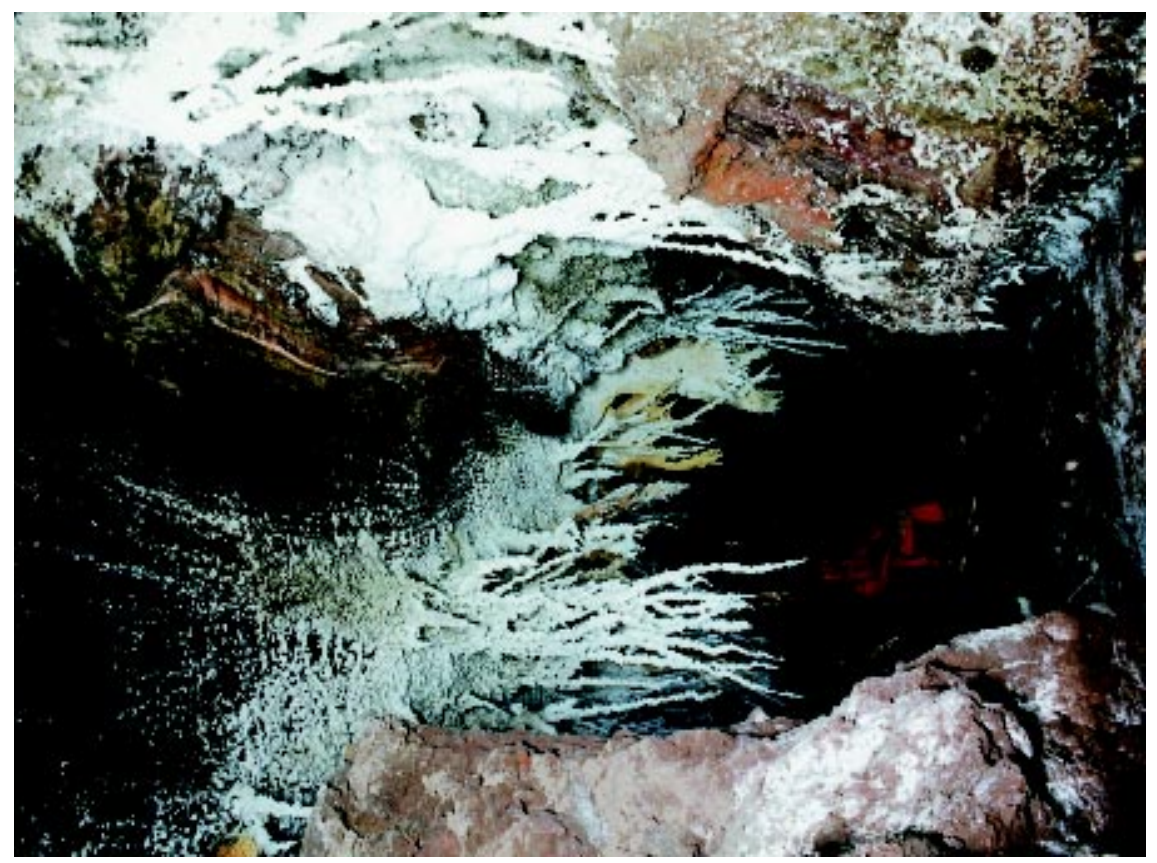

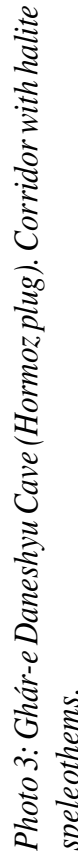




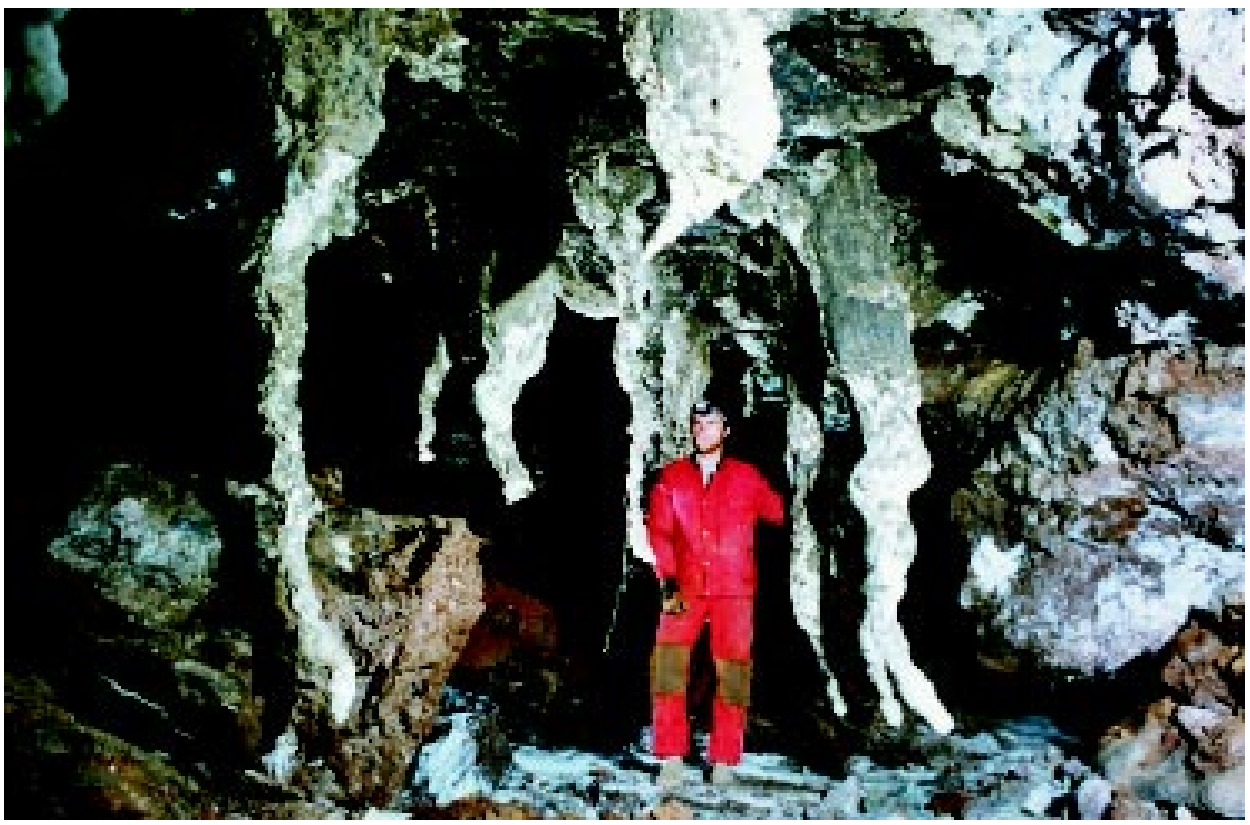

Photo 5: Ghár-e Daneshyu Cave (H8, Hormoz plug). Massive stalactites partly eroded by water.

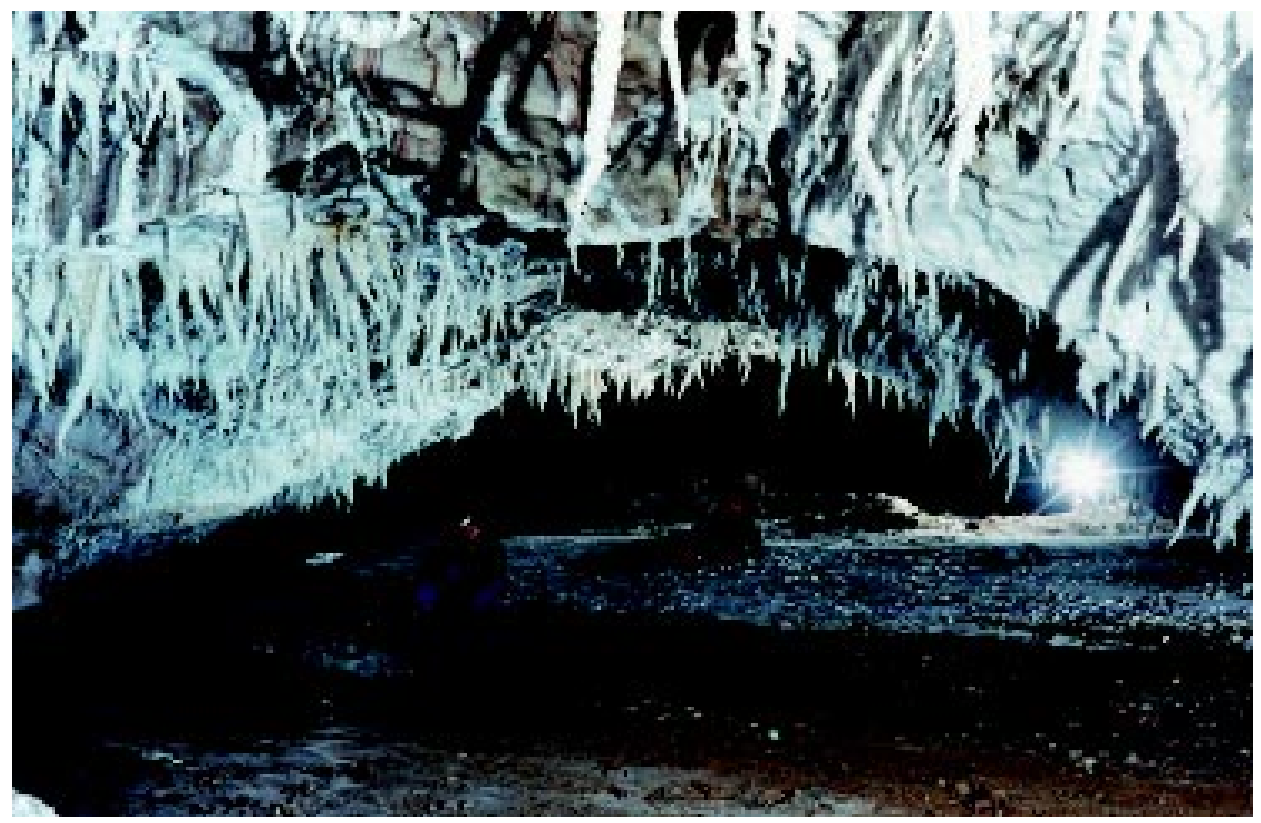

Photo 6: Namaktunel Cave (N1, Namakdan plug). Wide and low main corridor with stalactites. 


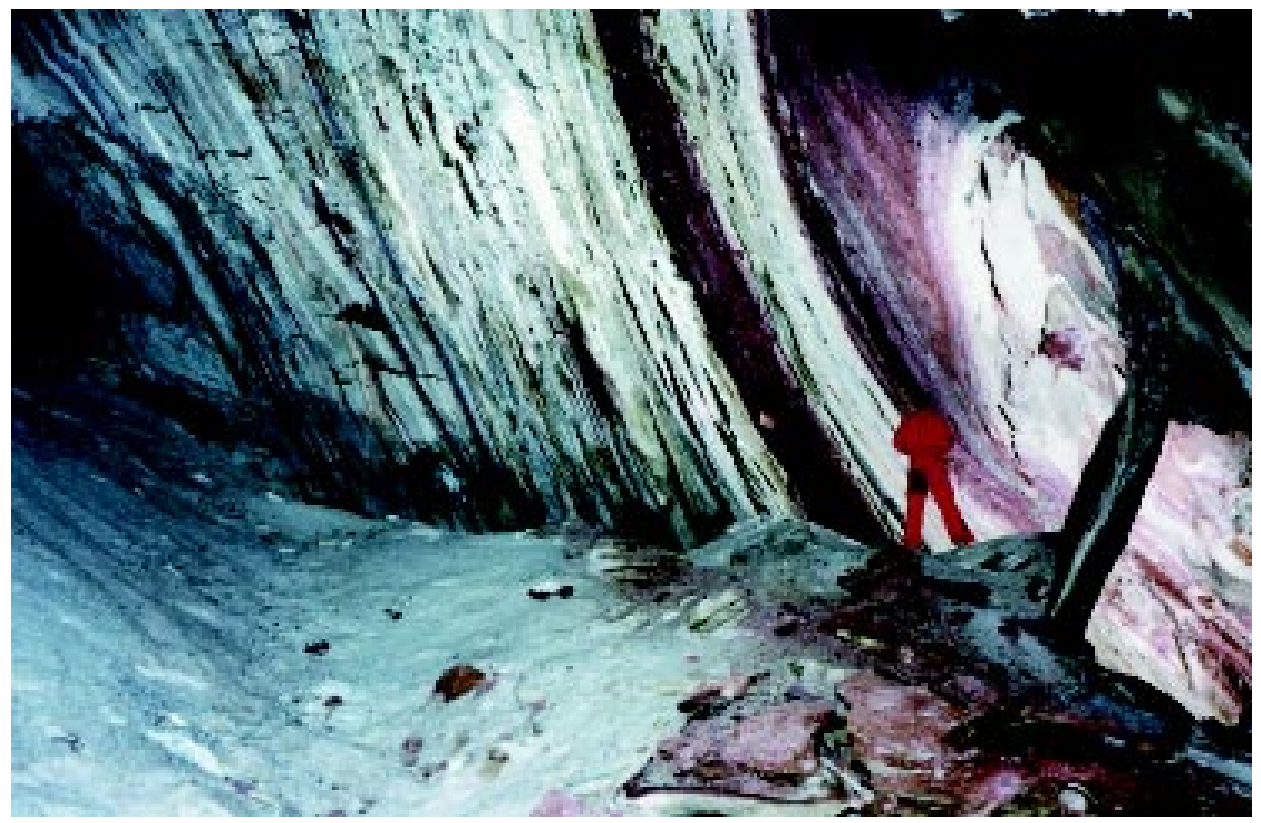

Photo 7: Namaktunel Cave (N1, Namakdan plug). Terminal dome.

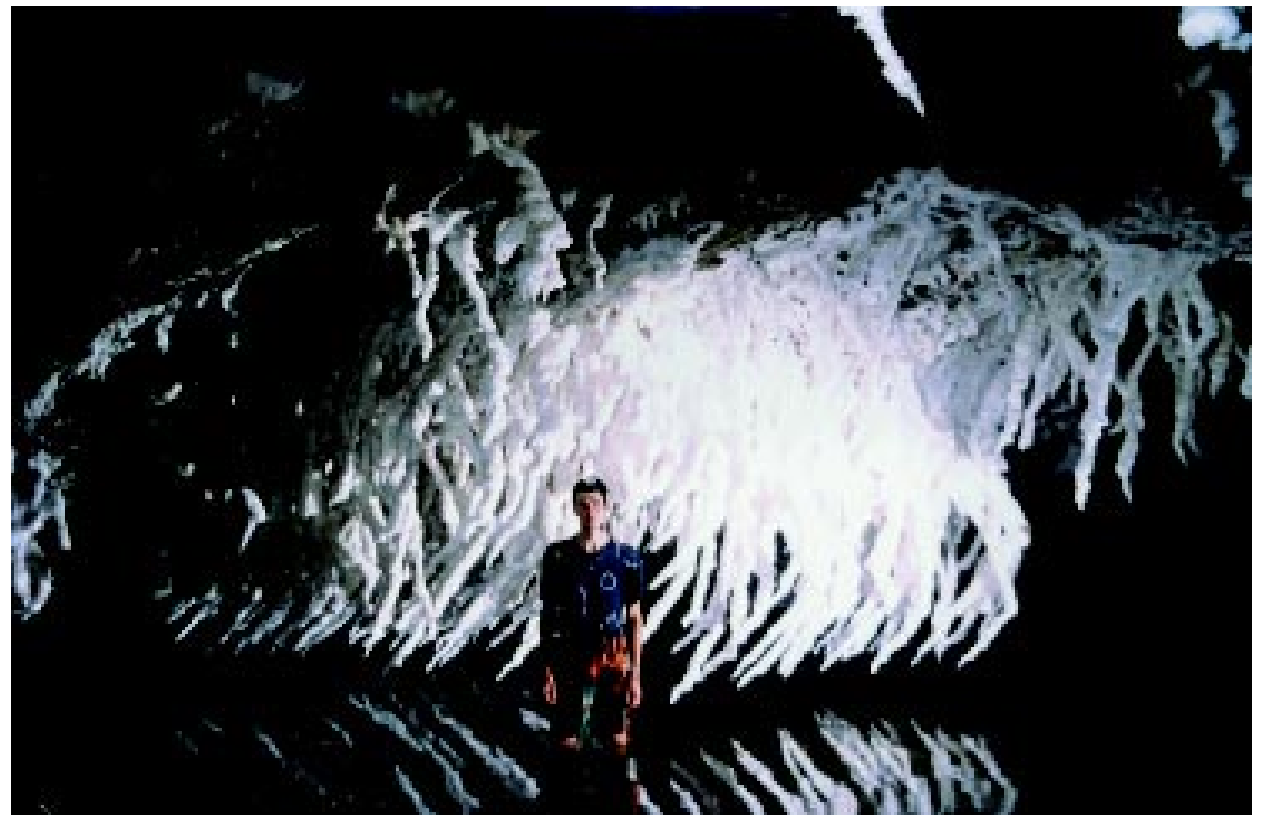

Photo 8: Cave of Tři naháčů (N8, Namakdan plug). Cave lake and curved stalactites. 
Blind valleys represent a common constituent of the plug landscapes, especially in less active ones. Their dimensions are smaller than in the classical karst regions with lengths of several hundreds of meters. They are mostly V-shaped with steep walls. Riverbeds of intermittent streams often cut sediments of bottoms (Photo 1). High and vertical closure wall with ponors is a common feature. Valleys are developed in salt and in brownish gypcrete, too. Short valleys at spring recharges are also common (steepheads or pocket valleys). They have high vertical closure wall, flat bottom with fluvial sediments and crusts of gypsum and salt.

Caves are developed in a wide variety of forms and sizes, from small-embryonic caves up to 2 to 3 level systems with lengths in kilometres. Caves are sometimes bound to polje-like forms. They are often open into bottoms of solution-collapse dolines. Caves can be classified mostly as integrated cave system (sensu Ford and Ewers 1978). Inlet caves defined by Frumkin (1994b) are rare, owing to poor exploration of plugs rather that due to their non-existence. In explored caves, show very wide and low vadose passages (Photo 6); often also paragenetic features responsible for flat roofs (Photo 2). Entrenched canyons are relatively rare. Steep vadose invasion passages (sensu Ford 1977) seem to be abundant, nevertheless very narrow for exploration. Collapsed and tension domes are common (Photo 7). Variety of smaller speleogens is not complete, as compared with limestone caves. Facets are indistinct owing to high salt solubility. No roof channels were found. Wall niches (Photo 2) are relatively common with a depth of several meters in places. Flat inclined roofs are typical features in numerous caves.

Ponors are mostly developed as swallow holes composed of inclined, step-like and vertical shafts often situated in solution-collapse dolines (inlet caves of Frumkin 1994b), at the end of blind valleys and in large depressions. They are situated both in salt and brownish gypcrete.

Karst springs often occur at foot of plugs, sometimes with developed steepheads. Hidden springs in alluvial cones are common as well as springs at foot of salt glaciers. Mineralisations of salt water in karst spring are about 360 to 370 g. l-1 (Fürst 1970, 1976; Bosák et al. 1998), i.e. similar to those given by Frumkin (1994a) from Israel.

\section{REGIONAL DISTRIBUTION OF KARST FORMS}

Two salt plugs were studied in detail by speleological expeditions, i.e. Hormoz and Namakdan plugs. Results will be mentioned in separate case studies. Other plugs visited during regional geological reconnaissance and by helicopter survey will be listed at the end of this chapter.

\section{Hormoz plug}

Hormoz plug (No. 1 in Fig. 1) is an island composed of salt plug with activity 1c encircled by marine terraces. Distinct karst features resulted from the differential salt solution. Karst forms represent a distinct part of the surface morphology (Fig. 2). There are numerous elongated to irregular solution- and collapse dolines, large uvala-like depressions, elongated asymmetric dolines with ponors. Karst springs are characterised by rich gypsum and salt precipitates (dams, salt crusts and sinters).

In detail, only the north-western part of the island was explored. Several caves were found and a rich spectrum of surface karst forms was noted. Features are listed in Fig. 2 as H1 to H20 and only the most important forms will be characterised in detail. Cave system H1 to H3 (System on Salty 


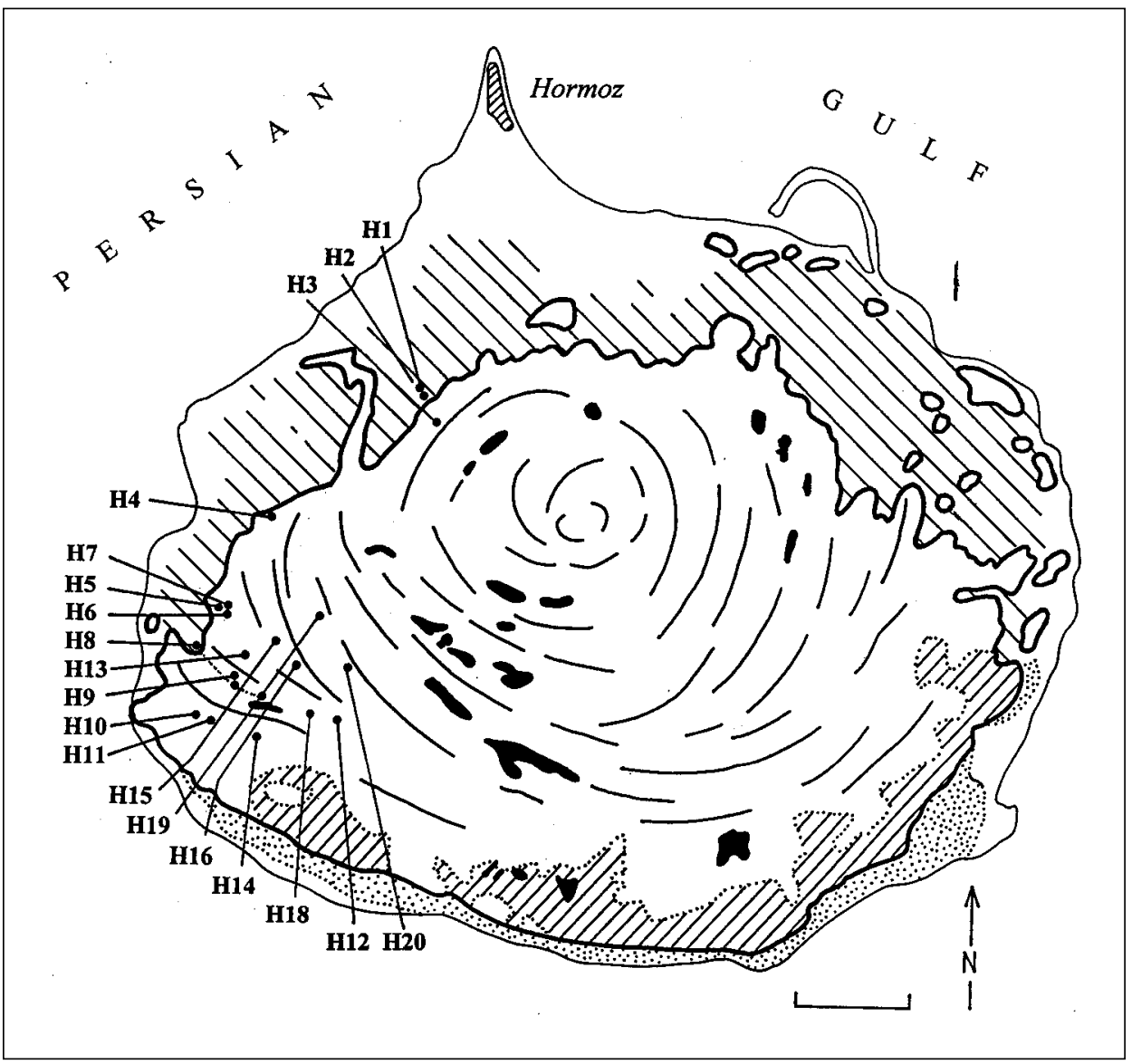

Fig. 2: Map of the Hormoz Island. Studied karst forms are numbered H1 to H20; (for explanations of symbols see Fig. 9; scale bar $=1 \mathrm{~km}$ ).

River) represents the system of ponor cave (H3 - Stalactite Forrest Cave) developed at the end of large blind valley (Photo 2) and outlet caves (H1 - Bottle Cave and $\mathrm{H} 2$ ) with relatively distant stable karst spring. The $\mathrm{H} 3$ cave is entered by a small entrance leading to a huge ( $3 \mathrm{~m}$ high and $3 \mathrm{~m}$ wide) passage about $70 \mathrm{~m}$ long with densely packed curved halite stalactites up to $3 \mathrm{~m}$ high. The cave follows bedding of rock salt. There are distinct relics of higher cave level $(+2 \mathrm{~m}$ above the river bed) in the cave wall. The cave ends by a sump lake of about $1.5 \mathrm{~m}$ deep, which drains towards cave $\mathrm{H} 2$. In the entrance part, side tributary $50 \mathrm{~m}$ long and $2 \mathrm{~m}$ wide with low roof and small stream (in February the discharge was $21 . \mathrm{s}^{-1}$ and temperature was $27.5^{\circ} \mathrm{C}$ ) ends again in a lake. The total length of the cave is about $150 \mathrm{~m}$. Outlet cave H1 (Bottle Cave) is small, not exceeding $50 \mathrm{~m}$ in length, with two entrances. Small spring flows out from one entrance. The cave is narrow, maze-like, probably phreatic in origin. Cave $\mathrm{H} 2$ with 4 entrances is composed of inclined passage $50 \mathrm{~m}$ long, 1.5 to $4 \mathrm{~m}$ high and 0.5 to $3 \mathrm{~m}$ wide with small water stream. The whole system can drain 


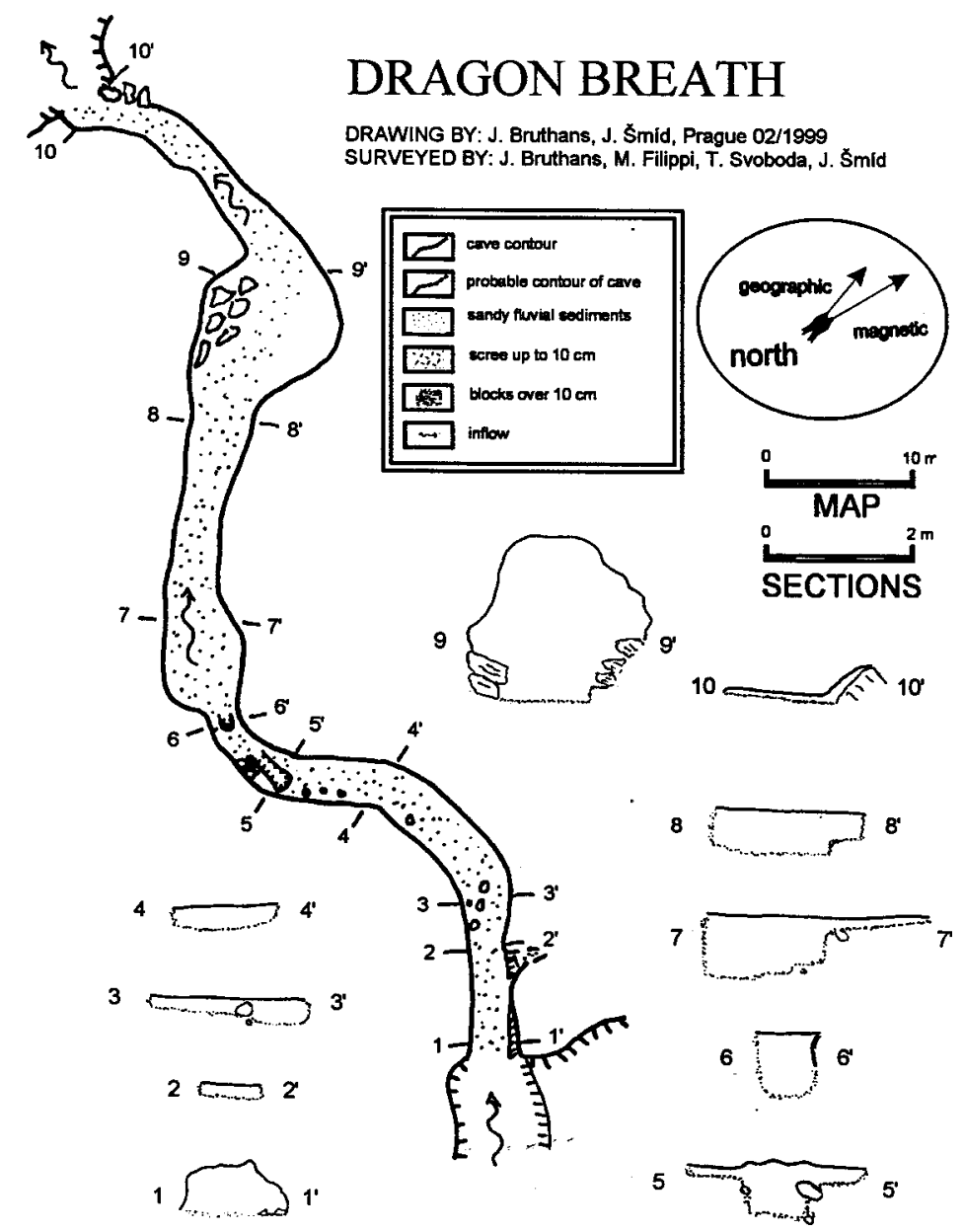

Fig. 3: Dragon Breath Cave (H5), map and sections.

a large area of the Hormoz plug as indicated by relatively high spring yields.

Cave $\mathrm{H} 4$ is developed in rock salt in hill above the marine terrace. It is formed by a steeply inclined $50 \mathrm{~m}$ long passage of invasion character with a small spring $\left(0-2 \mathrm{l} \mathrm{s}^{-1}\right)$. An eight meters deep circular shaft situated half way along the cave connects it with the surface. The cave ends at a big collapse doline.

Caves $\mathrm{H} 5$ and $\mathrm{H} 6$ are situated in a shallow valley filled with deluvia. Some other smaller caves (H7), numerous small ponors and subrosion sinks occur here. Cave H5 (Cave of Dragon Breath) has a length of about $100 \mathrm{~m}$ (Fig. 3). It consists of passages with differing morphologies and small halls with a minor water stream. Flat roofs with inclination of $5.4 \%$ are typical features. Passages cut down to cave sediments, which contain clasts up to $50 \mathrm{~cm}$ in size! The cave was repeatedly 
visited. On August 1997, a net of numerous stalagmites and stalagnates blocked the entrance. On March 1998, there were no remains of speleothems. On February 1999, the stalagmites appeared again, indicating the extremely high growth rates of halite speleothems. The cave originated by paragenesis with the lateral migration of channel followed by entrenchment of passage into accumulated cave sediments. The cave can be correlated with the surface of marine terrace $+20 \mathrm{~m}$. Cave H6 (Crystal Cave) is an outlet cave, slightly inclined, about $40 \mathrm{~m}$ long with low roof and rich speleothems. The small water stream has a stable discharge during dry seasons also. Cave H7 (Waterfall) is a collapsed ponor cave $30 \mathrm{~m}$ long with altitude difference of $15 \mathrm{~m}$.

Cave H19 (Meander Cave) is about $300 \mathrm{~m}$ long. It consists of an older level with a flat roof at $+3 \mathrm{~m}$ above riverbed and of a younger vadose meandering canyon.

The longest cave of the island is the 1,909 m long Ghár-e Daneshyu Cave, which is the world $5^{\text {th }}$ longest cave in salt (according to data in Chabert and Courbon 1997). It consists of three subparallel passages with intermittent water streams and some older passages (Fig. 4). The inclination of the system is about 4 to $7 \%$. The passages have three parts in a vertical section. The upper part with flat roof is situated some +4 to $+6 \mathrm{~m}$ above the active river bed. It is relatively wide (tens of meters are estimated). The middle part is represented by canyon-like entrenchment with the base from +0.5 to $+4 \mathrm{~m}$ above the active river bed. The lowest part is the recent level, which is broad but less extensive than the uppermost level. The river bed is filled by $2 \mathrm{~m}$ thick sediments. The water discharge of streams was about $21 \mathrm{~s}^{-1}$ during the exploration. The section named as Long Domes consists of a

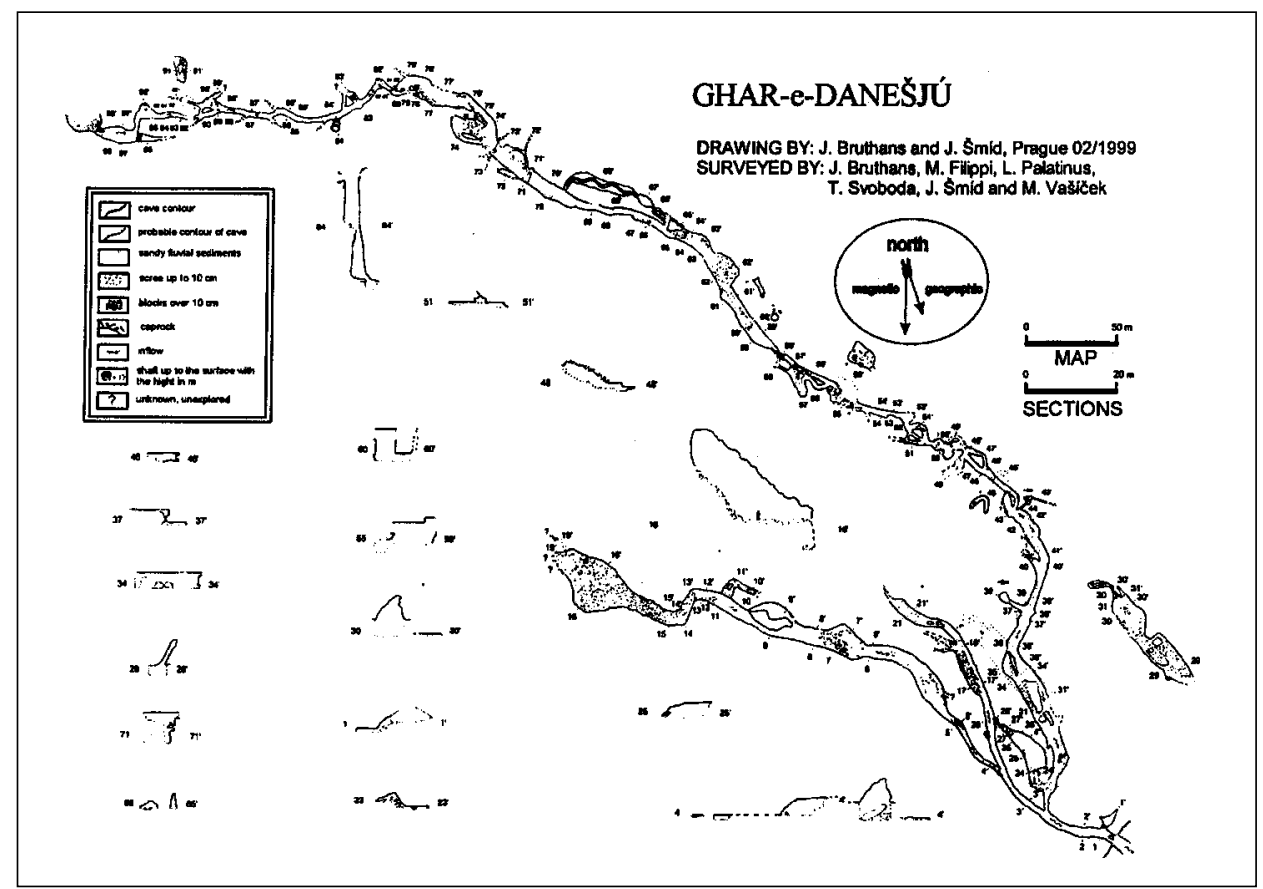

Fig. 4: Ghár-e Daneshyu Cave (H8), map and selected sections. 
relatively narrow passage with rich speleothems (Photo 3) leading to flat collapsed domes originated from about $6 \mathrm{~m}$ wide passage in steeply inclined salt beds. The water stream appearing in the Bozorgtarín Dome (Photo 10) probably drains cave H9 (Portal; Fig. 5; Photo 1). Another part of the cave, Passage of Fulfilled Wishes, is composed of low and relatively wide and slightly meandering passage with some larger collapsed domes and rich speleothem decoration in places (Photo 5). The water stream can be traced only some $50 \mathrm{~m}$; the rest of the branch is dry. Flat roof at about $+6 \mathrm{~m}$ is a distinct feature of this branch. The cave bottom ascends to a level of $+6 \mathrm{~m}$ behind the section named Canyon. Here, the passage cut down sediments of completely filled cave horizon with a width of more than $20 \mathrm{~m}$. The cave was developed in four evolution stages: (1) fall of base level entrenchment of blind valleys, origin of some parts of the cave (Canyon); (2) relative rise of base level - accumulation of alluvial deposits on the terrace; (3) stagnation or slight rise of base level paragenesis resulted in origin of wide level $+6 \mathrm{~m}$ with bevels and deposition of $2 \mathrm{~m}$ thick sediments,

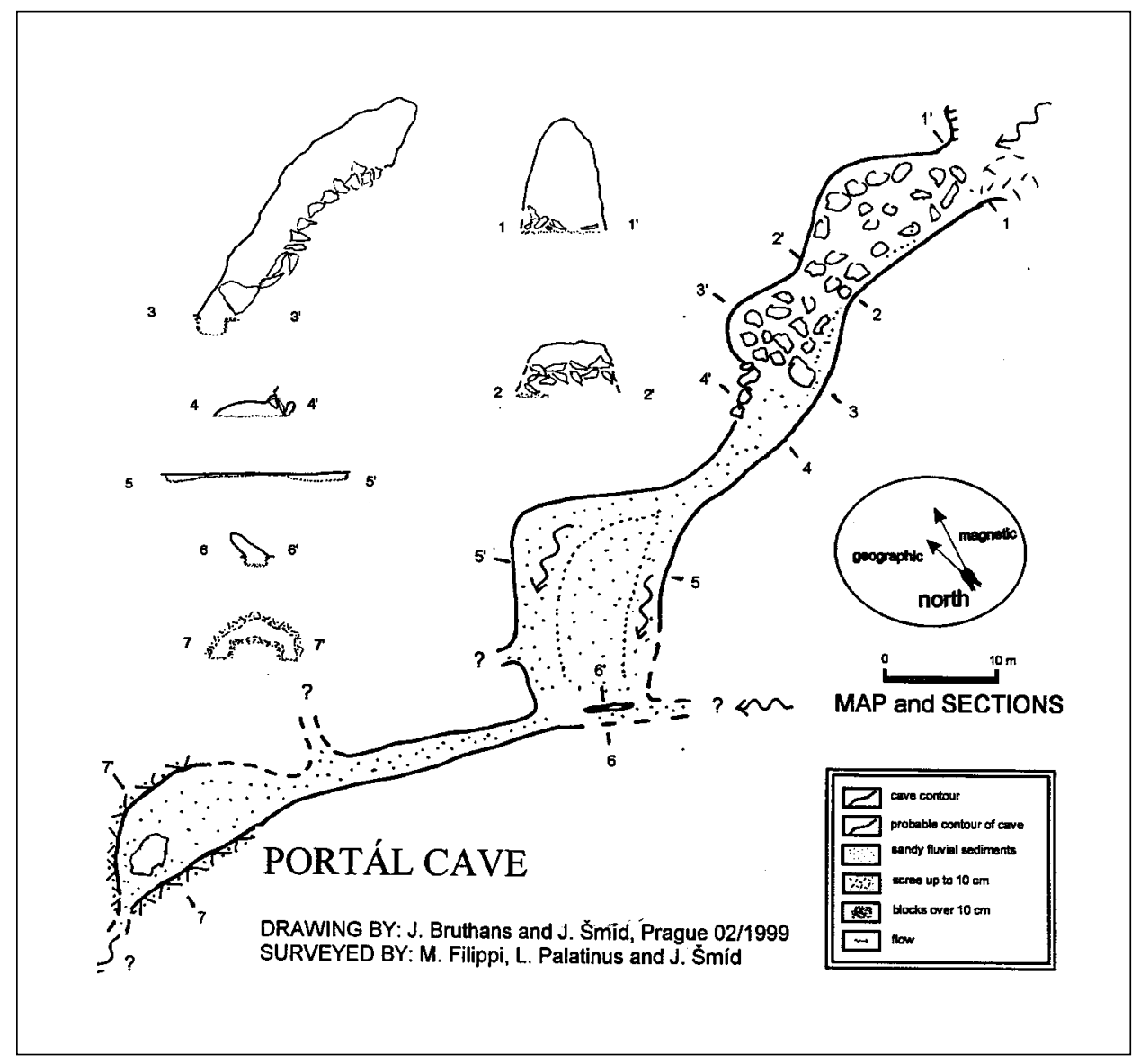

Fig. 5: Portal Cave (H9), map and sections. 
and (4) rapid fall of base level - entrenchment of canyons - followed by slower fall or stagnation at the recent level resulting in lateral corrosion and collapses. Bats were noted in the cave.

\section{Namakdan plug}

Namakdan plug (No. 4) is situated in the largest island of the region (Qeshm Island). Its activity can be classified as category 2a. Karst forms are very abundant (Fig. 6). Surface features are represented by solution and collapse dolines with a maximum depth of $43 \mathrm{~m}$. Some of them are filled with highly salty water. Numerous large depressions of the uvala or polje type are reported, too. Swallow holes continued by caves are situated at the plug margins, in blind valleys and in extensive depressions. Caves and cave systems with salt speleothems are abundant. The larger caves lie at the south-eastern part of the plug. Caves are often developed in several levels. Karst springs from caves yield about $0.21 \mathrm{~s}^{-1}$ in the dry season. Expressive salt crusts and sinters line springs.

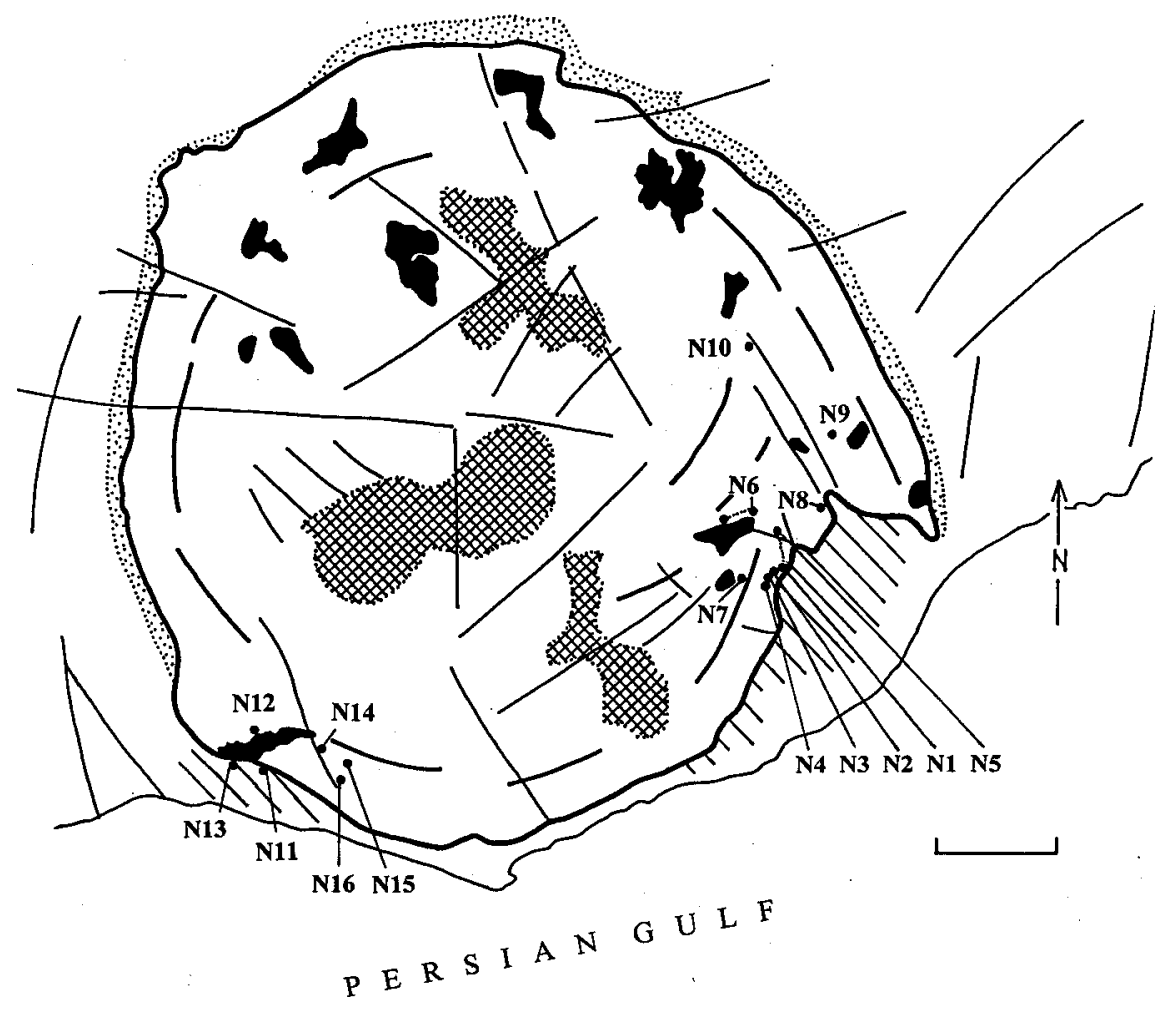

Fig. 6: Map of the Namakdan plug. Studied karst forms are numbered N1 to N16; (for explanations of symbols see Fig. 9; scale bar = $1 \mathrm{~km}$ ). 


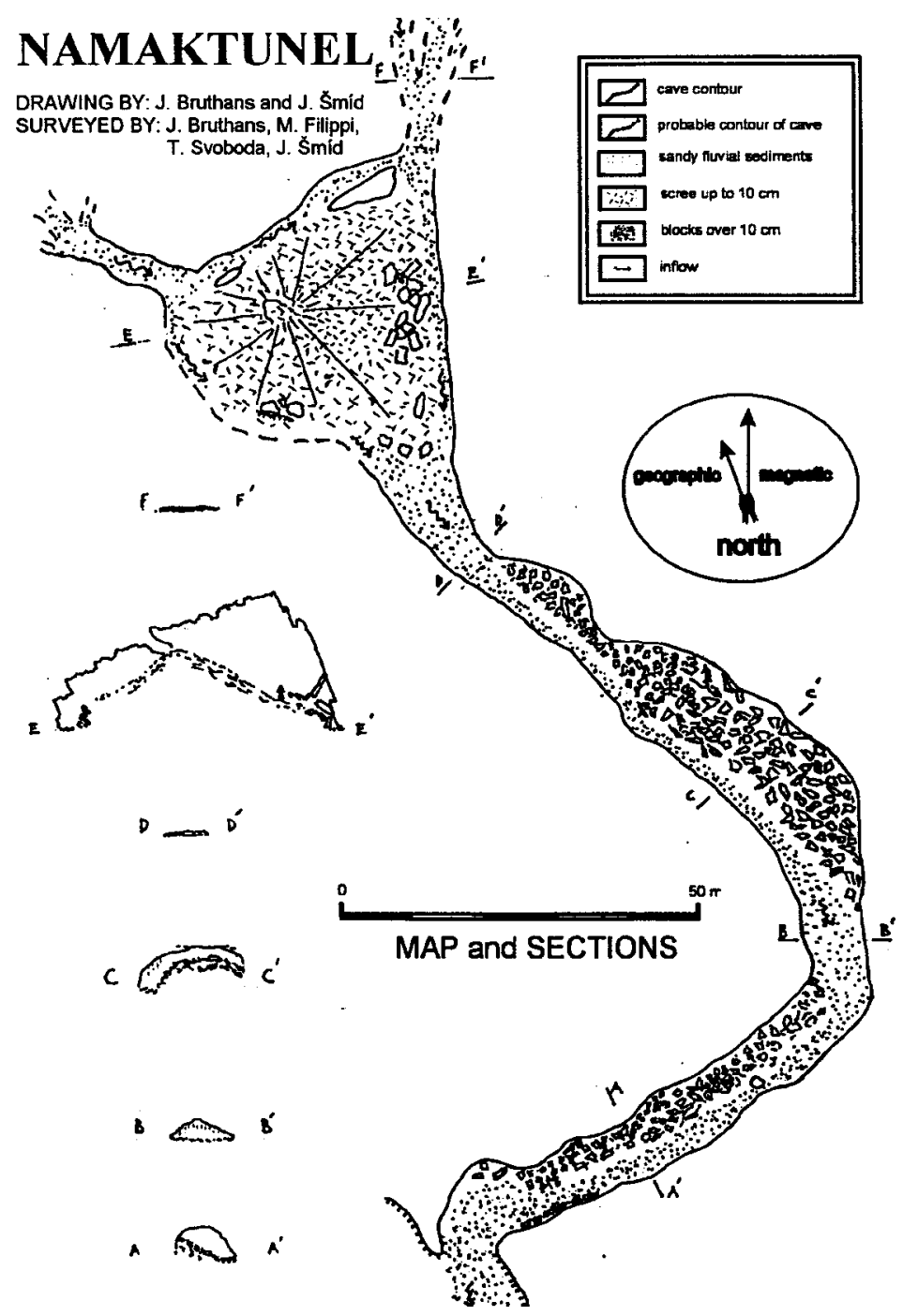

Fig. 7: Namaktunel Cave (N1), map and sections.

Detailed speleological exploration was carried out only in the south-eastern and southern portions of the plug. Features are listed in Figure 6 as N1 to N16, and only the most important will be characterised in detail. The most important caves in the south-eastern part of the plug are developed at the level of $+20 \mathrm{~m}$ marine terrace in the broad steephead. Samadian (1990) dated undisturbed sediments of this level to 30-6 ka (Dullab Alluvium), while older beach deposits of Qeshm Limestone (40 to $30 \mathrm{ka}$ ) are overturned, indicating the ceased (or interrupted) plug activity since lower Holocene. 


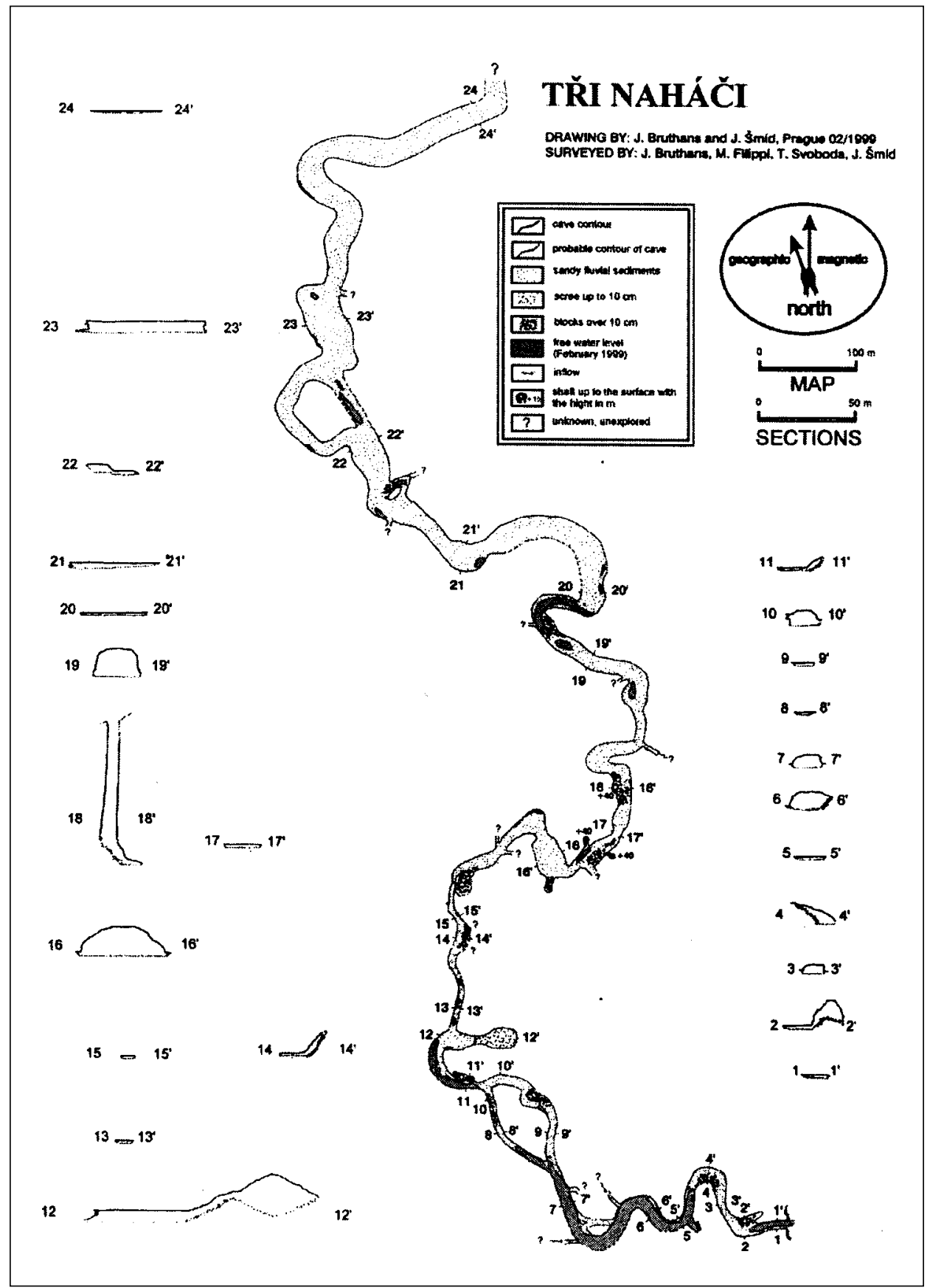

Fig. 8: Tř́ nahačů Cave (N8), map and sections. 
The Namaktunel Cave (N1; Fig. 7) is characterised by a large entrance ( 8 by $12 \mathrm{~m}$; Photo 4 ) and huge meandering river passage (Photo 6) with intensive collapses (Photo 7) and intermittent stream. After some $150 \mathrm{~m}$, a vertical wall interrupts the passage. Behind it, the passage is flat and leads to a large tension dome, which is about $20 \mathrm{~m}$ high, developed in steeply inclined salt beds. Channels carved by floodwaters encircle the dome. The continued collapse causes the lateral shift of erosional channels and enlargement of the space. Passages are partly filled by coarse-grained gravels. Salt stalactites up to $1 \mathrm{~m}$ long are abundant (Photo 6). The total length of the cave is about $400 \mathrm{~m}$. The Water Cave (N2) is a flooded cave passage with stable spring. An older level is developed at about $+10 \mathrm{~m}$ above the cave. Cave of Snow Kingdom (N3) is about $50 \mathrm{~m}$ long, a broad and low passage with small halls ending by a net of inaccessible narrow caves. Abundant salt speleothems are present, as well as the water stream. Bozorg Portal Cave (N5) has $15 \mathrm{~m}$ wide and $5 \mathrm{~m}$ high entrance north of the Namaktunel. It is represented by a large hall $(50$ by 25 by $15 \mathrm{~m})$ with a broad river valley filled by gravels at the bottom. The cave ends by a very low inaccessible passage. Polje Cave (N6) is developed along the northern slope of a large closed depression of the polje-type situated close to northeastern escarpment of the plug. Surveyed passages total $300 \mathrm{~m}$. The cave has a large entrance with a narrow channel cut down several meters to the polje bottom fill. The main huge passage is over $10 \mathrm{~m}$ wide in places and up to $15 \mathrm{~m}$ high, interrupted by tight parts and slowly descending to the limit of accessibility. A collapsed window $7 \mathrm{~m}$ deep connects the cave with the polje, too. Rich speleothems cover the walls. The water from the cave continues, most probably, through cave N5 into Namaktunel Cave. Light hole of Shaft of Strong Echo (N7) is opened in a wall of large blind valley by entrance ( 20 by $15 \mathrm{~m}$ ) leading to a large hall. In the bottom of the hall, there are other shafts visible. By inclined passages, the active water stream can be reached. The depth of this system is $60 \mathrm{~m}$. It is very probable that caves N4 and N7 represent a relic of larger cave system.

Cave of Tř́ naháčù (Cave of Three Naked Men, N8; Fig. 8) is the longest cave explored. With its 3,160 $\mathrm{m}$ is the world $3^{\text {rd }}$ longest cave in salt ( $c f$. Chabert and Courbon 1997). The cave consists of huge meandering passage opened by entrance $(8$ by $3 \mathrm{~m}$ ) in the western wall of outlet valley (the SE part of the plug). The entrance is filled with water. Another large lake, $300 \mathrm{~m}$ long and up to $1 \mathrm{~m}$ deep is developed at $160 \mathrm{~m}$ from the entrance behind a small collapse dam. There, the roof lies only at $+20 \mathrm{~cm}$ above the lake level in places. Abundant stalagmites are typical here (Photo 8). At $670 \mathrm{~m}$ from the entrance, the Hangar Hall is developed ( 35 by 20 by $16 \mathrm{~m}$ ). Behind this point, the passage width decreases from 10 - $15 \mathrm{~m}$ only to a maximum of only $6 \mathrm{~m}$. One kilometre from the entrance, there are several collapse domes (up to 40 by 20 by $15 \mathrm{~m}$ ). Here, three chimneys connecting the cave with surface are developed; they are about $40 \mathrm{~m}$ high and their mouths have not been located on the ground. Large bats occur here. From point at 1,450 m from the entrance, the passage changes to broad (more than $30 \mathrm{~m}$ ) but very low space. The roof is flat. At 2,100 m from the entrance, the cave width increased to $40 \mathrm{~m}$. This space is $90 \mathrm{~m}$ long and $4 \mathrm{~m}$ high. At the end of the surveyed cave the roof declines up to the limit of accessibility. The general inclination of the cave is only 3 per mills, so flat roofs could represent corrosional bevels here. The broad passage, especially in the distant part of the cave, originated due to lateral erosion and corrosion of salt by meandering of the stream. It cannot be excluded that the real cave width can reach $100 \mathrm{~m}$ in places. The fossil (older) level is developed at $+4 \mathrm{~m}$, where side niches are filled by up to $1 \mathrm{~m}$ thick sediment. The cave is developed in steeply inclined rock salt. The bottom is always covered with fluvial sediments (up to coarse-grained gravel). Preserved ripple marks can indicate high flood discharges of several cubic 
meters per second. The normal discharge of the water stream is about $11 \mathrm{~s}^{-1}$. About $1.5 \mathrm{~km}$ to the $\mathrm{NNE}$ of the cave entrance, large ponor (N10) is developed in narrow and deep canyon. The canyon entrenched the bottom of flat blind valley to the depth of $30 \mathrm{~m}$ and leads to a flat and wide cave passage, which was not explored. Connection with the Cave of Tří naháčů is highly probable.

Several features were explored also in the southern to south-western part of the plug margins (N11 to N16) in another steephead. The plug slope is rimmed by marine terrace $+20 \mathrm{~m}$, similarly to its south-eastern part. Bath Cave (N11) has a circular entrance (diameter of $4 \mathrm{~m}$ ) filled with water. The cave is represented by flooded passage (5-10 m wide and up to $1 \mathrm{~m} \mathrm{high}$ ), sometimes with collapses. Flat roofs (bevels) are developed at $+1 \mathrm{~m}$ and at the water level. A distance of $150 \mathrm{~m}$ was reached by swimming. The water discharge was $51 \mathrm{~s}^{-1}$. This resurgence probably drains karst forms N12 to N16. The ponor of large stream (N12) entrenched its bottom several tens of meters into brownish gypcrete. Several small ponors drain water to the Bath Cave which lies several hundreds meters to SSE. Fossil level at $+5 \mathrm{~m}$ lies above active ponors. Caves here have flat roofs and they are filled by sediment. The width of paleoponors reaches up to $15 \mathrm{~m}$. A huge shaft of the light-hole type (N14) is situated high in plug in a small plateau covered by brownish gypcrete. The rectangular opening ( 20 by $30 \mathrm{~m}$ ) leads to at least $50 \mathrm{~m}$ shaft developed partly in rock salt and partly in gypcrete (up to $40 \mathrm{~m}$ ). Double Doline (N15) is situated nearby. A now inactive sinkhole leads to vertical shaft with depth of more than $40 \mathrm{~m}$. Rock salt appears only at $-40 \mathrm{~m}$ below the brownish gypcrete and slope sediments with distinct subhorizontal lamination. The Pyritišti Doline (Doline full of Pyrite; N16) has diameter between 50 and $100 \mathrm{~m}$ and the depth is $20 \mathrm{~m}$. At the bottom, $20 \mathrm{~m}$ deep shaft is situated. Half of the shaft is carved in rock salt, the other in gypcrete.

\section{Other plugs}

The description of karst forms is according to results of regional geological reconnaissance and helicopter trips in 1992-1993 ( $c f$. Bosák et al. 1998). Data on two plugs, one outside the studied area, are added according to data of Fürst $(1970,1976)$.

Larak (No. 2; activity 2b, island). Enormous amount of karst forms are reported, especially of corrosional and collapsed dolines of elongated or irregular shapes, some of them more than $20 \mathrm{~m}$ deep.

Hengam (No. 3; activity 3, island). Collapsed dolines have diameter from 10 to $20 \mathrm{~m}$ and depth of about $10 \mathrm{~m}$. Walls of collapses are subvertical with cylindrical sculptures. Young sediments fill collapse karst dolines.

Berkeh-ye Suflin (No. 5; activity 2a). Karst depressions were registered at the eastern plug margin.

Bustaneh (No. 7; activity 2a). The plug periphery contains dolines and caves.

Moghuieh (No. 8; activity 2b). Dolines occur in the south-western segment of the plug. Larger depression was interpreted from air photos on the erosionally dissected summit plateau in the northwestern part of the plug.

Chiru (No. 9; activity 1c, with glacier). Karst features can be observed on the majority of plug surface, more commonly at margins of the plug proper, less frequently on the summit plateau (collapsed dolines, uvala-like depressions). The occurrence of large elongated depression in alluvial fans rimming the plug with lowest points at $37 \mathrm{~m}$ below s.l. can indicate subrosion of buried salt or unbreached masses followed by sinking of overburden.

Gachin (No. 10; activity 2c). Salt is preserved on the surface in many sites, especially at plug 


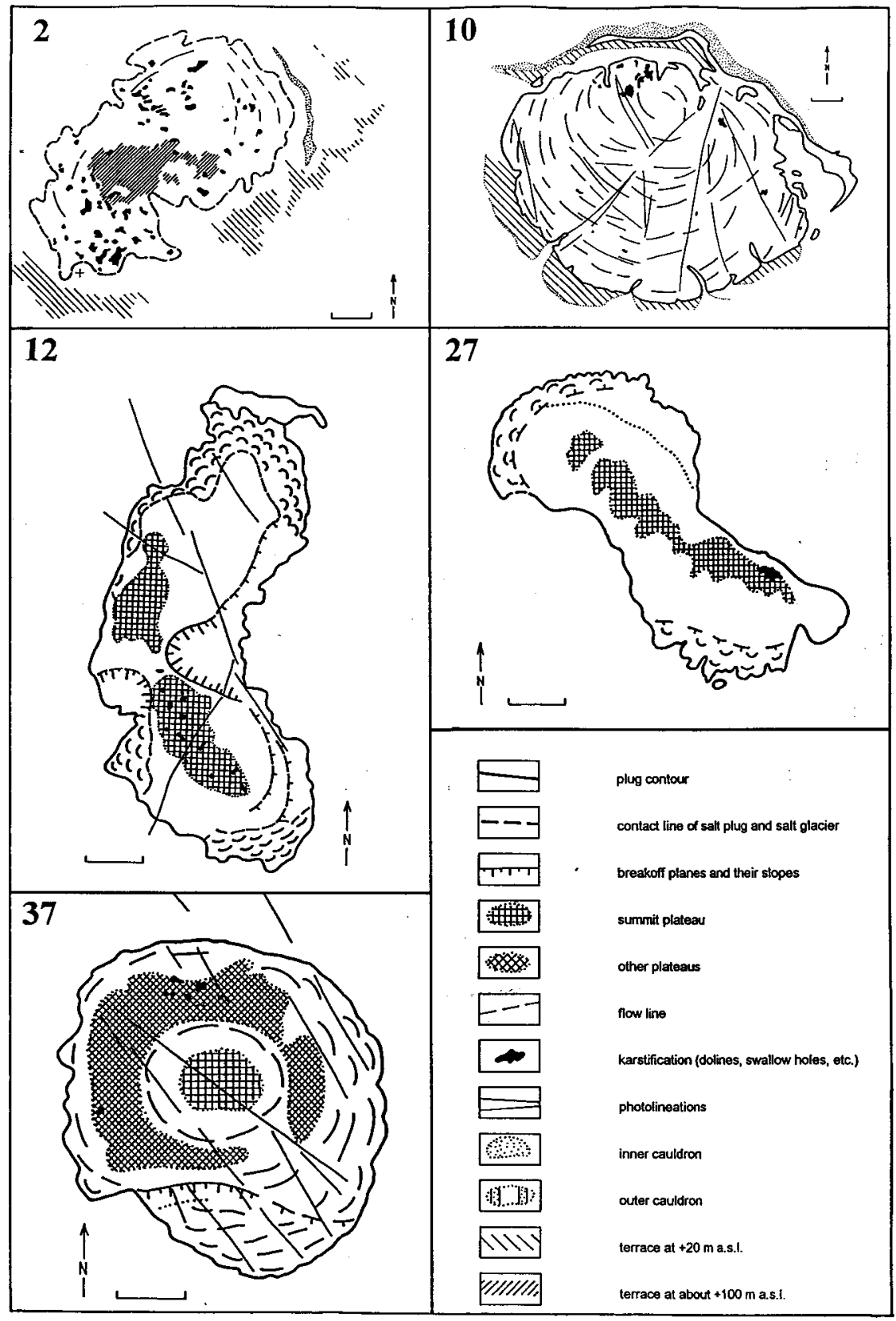

Fig. 9: Karst phenomena on the surface of some plugs. Karst forms in black. Scale bar $=1 \mathrm{~km}$ (for position of plugs see Fig. 1, for names of plugs see Appendix; courtesy of the Institute of Geology, Academy of Sciences of the Czech Republic, Praha). 
periphery, with numerous karst phenomena (solution and collapse dolines, small caves and shafts, with diameters more than $15 \mathrm{~m}$, karren to pinnacles, vertical columns, etc.). Larger depressions are concentrated especially at the northern plug margin.

Puhal (No. 11; activity 1a, with glacier). Karst depressions are developed in summit vaulted plateau (dolines to shafts), where brownish gypcrete, laminated (hematite) in places is developed. Salt glaciers are only slightly karstified by small karren.

Khamir (No. 12; activity 3, central part 2c). Although in a high degree of ruination, relatively abundant surface and underground karst forms occur (swallow holes, collapsed and solution dolines, caves, karren, pinnacles, etc.; Bosák 1993). Swallow holes in salt can drain precipitation from an extensive region of central part of amphitheatre in eroded junction of Khamir and Puhal Anticlines.

Zendan (No. 15; activity 2b). The western plug limit is built up of step-like surface connecting the plug and Tertiary Agha Jari and Mishan Formations in which the summit at 1,043 m a.s.l. occurs above a small relic of levelled surface at 900 to $1,030 \mathrm{~m}$ a.s.l. It cannot be excluded that levelled surfaces at 1,043 m a.s.l. on Tertiary sediments and at 600 to $700 \mathrm{~m}$ a.s.l. on the plug represent originally uniformly levelled surface differentiated along structural lines and by salt solution.

Champeh (No. 16; activity 2b). Karst features (solution pipes) as well as collapses and folding of Quaternary sediments due to salt subrosion were observed.

Chah Musallem (No. 17; activity 2a). Karst depressions (collapse dolines, etc.) were registered in places, sometimes they are numerous. Karst collapses can drain surface waters at plug margins. Some caves are visible on bottoms of some solution dolines.

Charak (No. 18; activity 2c). Karstification is not abundant.

Anguru (No. 21; activity 1a, with glacier). Numerous karst depressions were observed, especially in salt glacier. Summit plateau is also highly covered by dolines.

Gezeh (No. 24; activity 1b, with glacier). Karstification was registered in the southern part (dominantly karren).

Khurgu (No. 27; activity 1a, with glacier). Karst forms occur (karren, dolines, collapses, and caves) especially on summit plateau(x) and in the salt flow.

Genow (No. 28; activity 3). Salt is exposed at the surface in some places; its occurrences being conspicuous by the presence of karst forms (solution and collapse dolines).

Bam (No. 31; activity 2a). Karst phenomena are developed especially at the eastern margins. Harrison (1930, p. 481) described large dolines and caves within the salt glacier.

Pordelavar (No. 33; activity 2c). Salt was detected at the western plug margins in highly corroded state (ovate collapses, pinnacles, and karren).

Bongod-e Ahmadi (No. 35; activity 2c). Relics of banded salt occur in the central part. Distinct collapsed dolines and swallow holes are present there.

Finu (No. 37; activity 1a, with glacier). Karst depressions were registered in the northern part of the plug.

Shamilu (No. 41; activity 1c, with glacier). Karstification is characteristic for the W glacier margins.

Chahal (No. 43; activity 1a, with glacier). Numerous karst forms (dolines, collapsed dolines, keyhole-like small caves in several levels, karst spring discharging from caves) were registered in salt glaciers. Outflows of highly mineralised waters from numerous fissures and from cavities at plug/glacier bottom. 
Siah Tagh (No. 44; activity 1c, with extensive glacier). Initial karst forms occur on the surface at the north.

Khain (No. 47; activity 1c). Halite prevails in the northern plug segment, forming morphologically distinct pinnacles.

Aliabad (No. 49; activity 1b). Numerous karren and embryonic cave systems in limestones indicate relatively slow water circulation. Karst forms are filled with Recent and Subrecent proluvial deposits.

Palangu (No. 51; activity 3). Karst depressions were occasionally registered in the plug.

Mesijune (No. 52; activity 1c, with extensive glacier). The karstification in the marginal glacier is frequent - karren to pinnacles dolines, collapsed structures, swallow holes and small caves.

Kurdeh (No. 53; activity 1c, with glacier). Karst phenomena in salt are abundant - vertical solution pipes, collapsed dolines, karren, etc.).

Deh Kuyeh (No. 54; activity 1b, with glacier). The frontal slopes of glaciers are up to $60 \mathrm{~m}$ high. Karst forms are abundant in them, dolines being the most common features. During wet season, numerous karst springs from glaciers were registered with yields up to $30 \mathrm{l} \mathrm{s}^{-1}$.

Nina (No. 55; activity 2b, complex vein). Karstification of plug material was registered in places - mostly dolines and solution pits.

Namaki (No. 56; activity 1c, with glacier). Karstification is abundant - numerous solution and collapse dolines, and solution pits up to $30 \mathrm{~m}$ deep.

Saadat Abad (No. 59; activity 1b). Numerous karst forms were registered on levelled surfaces on sides of the plug - shallow funnel-shaped dolines with diameters of about $10 \mathrm{~m}$.

Gahkum (No. 60; activity 2c). Fürst $(1970,1976)$ reported about $400 \mathrm{~m}$ of accessible cave passages at the foot of the plug. White stalagmites and stalactites decorate the cave. Underground stream was noted, too.

Bana Kuh (No. 64; activity 1c). Karst forms are abundant with common dolines.

Fürst (1970, 1976-Tab. 1/Fig. 1) reported extensive occurrences of dolines on the summit plateau of the Kuh-e Jemal plug (near Firuzabad). The plug can be classified as morphodynamically active (category 1b).

\section{NOTES TO GENESIS OF KARST FORMS IN SALT}

Karst in salt plugs is relatively common. Chabert and Courbon (1997) report occurrence of karst is rock salt from several states: Algeria (in diapirs, mostly shafts, short caves to $280 \mathrm{~m}$ ), Chile (caves 500 and $250 \mathrm{~m}$ long), Israel, Romania (second longest cave of the world with 3,234 m of passages), Spain (in diapirs, caves up to $650 \mathrm{~m}$ long), Syria, Tadjikistan (several caves 300 to 2,500 $\mathrm{m}$ long and up to $120 \mathrm{~m}$ deep) and Tunisia (caverns in diapirs). Caves of Mount Sedom in Israel are developed in one diapir. There are known four caves longer than $1 \mathrm{~km}$, with the longest salt cave of the world with 5,685 m of passages (i.e. the Malham Cave; $c f$. Chabert and Courbon 1997). Detailed description and review of evolution of salt caves in Mount Sedom is given by Frumkin (19821996), who stated principles of speleogenesis in salt. Our observations are generally in accord with them, concerning e.g. the character and form of surface drainage, role of base level and cap rock/ brownish gypcrete, character of karst springs. Nevertheless some specific features occur within Zagros salt plugs, on which we will comment here. 


\section{Activity of plugs and kartification}

During our exploration, we detected the occurrence of karst forms on 36 plugs from 68 studied. Six plugs were studied only on air photos, on which smaller karst forms, like karren, small dolines, cave openings, cannot be visible here; only larger depressions can be contoured on air photos according to our experience from other plugs (Bosák et al. 1998).

The statistics concerning the occurrence of karst forms and plug activities showed surprisingly abundant karst phenomena in active plugs ( $50 \%$ from all plugs with detected karst; Table 1). About $40 \%$ plugs with karst belong to the category of passive plugs. Activity sub-categories $1 \mathrm{c}$ to $2 \mathrm{~b}$ represent the most abundant plug categories hosting karst forms (some $55 \%$ ).

Table 1: The distribution of karst forms within salt plugs according to plug activities.

\begin{tabular}{|l|l|lr|}
\hline Plug activity & Number of plugs with karst & Percents & \\
\hline $1 \mathrm{a}$ & 5 & 13.9 & 50.0 \\
$1 \mathrm{~b}$ & 4 & 11.1 & \\
$1 \mathrm{c}$ & 9 & 25 & 40.3 \\
\hline $2 \mathrm{a}$ & 5 & 13.9 & \\
\hline $\mathrm{b}$ & 6 & 16.7 & 9.7 \\
\hline $\mathrm{cc}$ & 3.5 & 9.7 & \\
\hline 3 & $3.5^{*}$ & 9.7 & \\
\hline
\end{tabular}

These data indicate that karst forms occur also on highly active salt plugs, often with salt glaciers. Karst develops dominantly in such active plugs, where summit vaulted plateaux or other type of levelled surfaces occur, at least in relics. The presence of flat surfaces indicates the pulses in diapirism with interruptions of plug activity. During periods of less active or ceased diapirism, planation surfaces developed and evaporitic rocks were altered to brownish gypcrete at the surface. This was the proper time for development of karst, which is a rapid process. After the diapirism renewed, karst forms were integrated, even within glaciers. Properties of glaciers enable easier development of karst owing to higher permeability and infiltration rate of precipitation. Fissuration and other features similar to séracs of ice glaciers ( $c f$. also Harrison 1930) caused the dissection of developed brownish gypcrete enhancing both infiltration and karstification (subrosion).

\section{Position of large caves}

The predominant number of caves found during regional geological reconnaissance and by later speleological explorations is developed in some of coastal salt plugs or on islands. Even during detailed geological mapping of inland plugs, no large caves were discovered, except only single small openings. In the coastal region, caves are clearly bound to the youngest marine terraces (both accumulation and abrasion). They are situated at +15 to +20 ( +25 max.) $\mathrm{m}$ a.s.l. (Hormoz and Namakdan plugs). The terraces are developed along nearly the whole coast and on all islands. Relics of this terrace level were found around Larak (No. 2), Hengam (No. 3), Berkeh-ye Suflin (No. 5), Band-e Muallem (No. 6), Moghuieh (No. 8), Chiru (No. 9) and Gachin (No. 10) plugs (for position see Fig. 1). The link of large caves and this marine terrace can serve as a good tool for future explorations in plugs close to the coast or in plug-islands. 
The link of large caves and marine terrace can indicate an important role of long-lasting stabilisation of the piezometric level forming favourable conditions for origin of continuous cave levels. Similarly to a coastal zone, river terraces were documented in inland plugs at +5 to $+10 \mathrm{~m}$, +15 to $+10 \mathrm{~m},+30 \mathrm{~m},+60 \mathrm{~m}$ and +80 to $+100 \mathrm{~m}$ a.s.l. (Fürst 1970; Bosák et al. 1998). The terraces correspond to marine abrasion/accumulation terraces found at seashore and on near-shore islands at +5 to $+10 \mathrm{~m},+10$ to $+15 \mathrm{~m},+15$ to $20 \mathrm{~m},+25$ to +30 (40) $\mathrm{m},+60 \mathrm{~m}$ and +80 to +100 (120) $\mathrm{m}$ a.s.l. (cf. also Kent 1958 or Gansser 1960). Especially the terrace at +80 to $+100 \mathrm{~m}$ a.s.l. is distinctly traced by a thick sedimentary marine/continental deposits (e.g. Bustaneh [No. 7] and Moghuieh [No. 8] plugs; Bosák et al. 1998). Within some plugs (e.g. Band-e Muallem, No. 6), bottoms of large depressions are situated at such altitudes. The occurrence of caves linked with such marine and/or river terraces seems to be highly possible. Such a link can serve again as very useful exploration tool. Nevertheless, the older the terrace levels are, the higher is the probability of discovering only relics of caves owing to a rapid velocity of karstification process in salt (both speleogenesis and chemical denudation/salt alteration to gypcrete/cap rock).

\section{Role of salt lithology and tectonics}

Dominant number of caves in Hormoz and Namakdan salt plugs are developed in inclined to steeply inclined salt beds with a dip over $40^{\circ}$, usually $70-90^{\circ}$. Fissures and faults oblique to perpendicular to salt bedding are rare without distinct influence on karstification (except the cave H1). Cave passages are usually developed along bedding planes. Salt bedding influenced collapses and governs the shape of most of domes. The evolution of tension domes is common. The mechanical al properties of salt in roofs of high domes can lead to the formation of huge cracks. The movement along such blocks was documented in Hangar Dome (Cave of Tří naháčù). The salt plasticity does not influence even extensive bevel-like structures in the Cave of Tří naháčů, which are $40 \mathrm{~m}$ wide. The closure of salt passages (Bögli 1980) probably starts only in a substantial depth and near-surface cavities similar to those described in Israel or Zagros Mts. are not affected by this process.

\section{Role of gypcrete/cap rock}

The role of cap rock was stressed by Frumkin (1994b). Similarly, the brownish gypcrete contributes large amount of clastic load in waters, especially during floods. Traces of redeposition, distinctly preserved in the brownish gypcrete indicate its downslope movement or movement in direction of ponors. In the Hormoz plug, there are dolines filled with thick accumulation of gypcrete, often lithified to the crust. The gypcrete can choke the drainage route even in a single flood event. During chemical denudation of salt, filled dolines prevented from corrosion, are reversed to hills. It seems that the gypcrete thickness influences the morphology of plug surface. It can be stated that the thicker the gypcrete the larger are dolines. Thin caprock enables corrosion of salt and origin of a dense network of smaller dolines. Massive and thick gypcrete enables water circulation only where disturbed, and places of infiltration are not so common, resulting in more concentrated water flow from large catchment area. All discovered caves with lengths over $300 \mathrm{~m}$ are situated under brownish gypcrete with thickness at least $5 \mathrm{~m}$ ( $c f$. also Frumkin 1994b). The properties of brownish gypcrete favour also the origin of vadose invasion caves (sensu Ford 1977). 


\section{Origin of domes}

Domed caverns originated mostly due to collapse of salt beds, often in the form of the tension dome. Collapsed material forms cones of stones and blocks at the cave bottom. Owing to the fact that most domes are developed along streams, the collapsed material pushes river beds towards dome walls. The river bed undercuts the dome walls. Enlargement of caverns causes a gradual increase in rock mechanical disequilibrium, which leads to continuing collapses.

\section{Fossil cave levels}

Fossil cave levels can occur elsewhere in the plug in relation to local base levels of large depression. Relation to sea level is not necessary. Such channels were observed. They are completely filled with sediments and have small diameter. Their altitude position is variable.

All older levels discovered in caves (e.g. H8, H19, N8, N11, N12) show flat roof at nearly identical position of +6 to $+4 \mathrm{~m}$ above the present river bed (except where artificially increasedN12). Roofs are not ideally horizontal, but inclined parallel to the bottom of the cave with measured inclination from per mills to about $11 \%$ ! Although resembling typical corrosional bevels, they are products of different process. As all such levels are completely filled by sediments, we connect those features to the products of paragenesis, except very gently inclined ones. In outlet and some of inlet areas, about $5 \mathrm{~m}$ thick alluvia were noted, entrenched by younger riverbeds. It seems that sea level rise during the accumulation of $+20 \mathrm{~m}$ terrace (30 to $6 \mathrm{ka}$, Samadian 1990) was composed of several oscillations (there are known levels at +25 to $+30 \mathrm{~m}$ in the Hormoz Island). The last one terminated at about $+5 \mathrm{~m}$ above the general level and caused slow increase of piezometric level and its stagnation resulting in the paragenesis due to heavy load of runoff waters. Erosion accompanied by cut of river beds is typical the time after regression. Back erosion has been still active, but does not reach far from the seacoast. In the Ghár-e Daneshyu Cave (Hormoz Island), water follows level $+6 \mathrm{~m}$ at a distance of $200 \mathrm{~m}$ far from the ponor.

\section{Notes on speleogenesis}

Owing to the character of salt karst, true phreatic forms are preserved only rarely. The reasons were comprehensively summarised by Frumkin (1994b, pp. 87-88). It seems that caves in Zagros plugs developed along the phreatic/vadose boundary, within the zone characterised by sudden

Table 2: Inclination of passages and estimated discharges.

\begin{tabular}{|c|c|c|}
\hline Cave & $\begin{array}{c}\text { Inclination of passages } \\
(\%)\end{array}$ & $\begin{array}{l}\text { Estimated flood discharge } \\
\left(1 . s^{-1}\right)\end{array}$ \\
\hline \multicolumn{3}{|l|}{ Ghár-e Daneshyu } \\
\hline - southern branch upper course & 7 & $\mathrm{X} 0$ \\
\hline - southern branch lower course & 4.3 & X0 \\
\hline - northern branch & $4.4-4.9$ & $\mathrm{X} 0-\mathrm{X} 00$ \\
\hline Cave of Dragon Breath & 5.4 & XO \\
\hline $\begin{array}{l}\text { Tributaries to the Cave of Tř } \\
\text { naháčů }\end{array}$ & 4 to 7 & Xo \\
\hline $\begin{array}{l}\text { Bath Cave, Cave of Tři } \\
\text { naháčů }\end{array}$ & 0.3 & X000 \\
\hline
\end{tabular}


oscillations of groundwater level during individual floods. Proto-channels could propagate along water/air interface or even exclusively within vadose conditions saturated after storm by water with high solution capacity.

The correlation between the inclination of cave passages and detected/estimated flood discharge seems to be highly probable (Tab. 2). The correlation can be explained by a rate of load capacity of water increasing with the water volume (velocity and hydraulic head). Therefore, the inclination of side passages has to be greater than of main conduits not to be choked by sediments.

\section{Origin of dolines and depressions}

The connection of deeper and larger dolines and depressions to underground streams is clear. Water streams, especially during floods, transport huge amounts of surface material coming dominantly from brownish gypcrete and related residua, sometimes also from areas outside plugs (personal observation of P. Bosák in 1988). Only a volume adequate to salt dissolution, i.e. comparably slowly can deepen depression without developed surface and underground drainage.

The evolution of some vertical solution-collapsed dolines can be explained by an example from the south-western part of the Namakdan plug ( material similar to brownish gypcrete was reported in one wall up to the depth of $40 \mathrm{~m}$, while the other wall showed normal thickness of the crust. Sedimentary textures in the material similar to gypcrete indicate the reworking of original crusts and water transport. The mechanism is clear from Fig. 10 and can be compared to the evolution of invasion vadose caves (sensu Ford 1977).

\section{Karst processes}

Karst processes in salt of plugs in the SE Iran have several characteristic features:

(1) Subrosion (solution in depth) below cap rock or gypcrete is a one of the principal processes during the origin of karst. The subrosion induces the origin of a great variety of karst forms. In the comparison with classical karsts in limestone the role of subrosion is much greater.

(2) Salt plugs represent drainage routes for precipitation. Karst forms in plugs drain sometimes large surface areas within plugs proper and outside (Khamir plug, No. 12; Bosák 1993). This function can explain a ,surprising amount of salt water“ in numerous plugs ,,in spite of desert environment" (Gansser 1960). The deep circulation of meteoric waters through karst porosity within plugs is responsible for such behaviour. The deep circulation enhances the subrosion processes in salt. In general, evaporitic rocks without karstification are impermeable and form aquitards. In zones affected by jointing, permeability increases, and, due to good water solubility, zones of high permeability are formed. Locally, they can have high accumulation capacity and create ways of transfer of groundwater. The medium stage of plug disintegration is hydrogeologically the most active one.

(3) Waters from salt plugs infiltrate in the depth to surrounding non-evaporitic porous media (Cretaceous to Tertiary carbonate rocks, Tertiary siliciclastics) supporting their deep-seated aquifers (Bosák 1993). In numerous cases, springs of hot water occur close to plug margins (Khamir-No. 12, Genow-No. 28, Anguru-No. 21, Kurdeh-No.53, Tarbu-No. 39; for plug position see Fig. 1). Temperatures vary from 35 to $60{ }^{\circ} \mathrm{C}$ (Václavek in Bosák et al. 1998). If we consider the value of normal thermal gradient, then it results that e.g., water of the springs of the Anguru Anticline at $47{ }^{\circ} \mathrm{C}$ has its circulation paths in a depth of around $700 \mathrm{~m}$, while water of the 

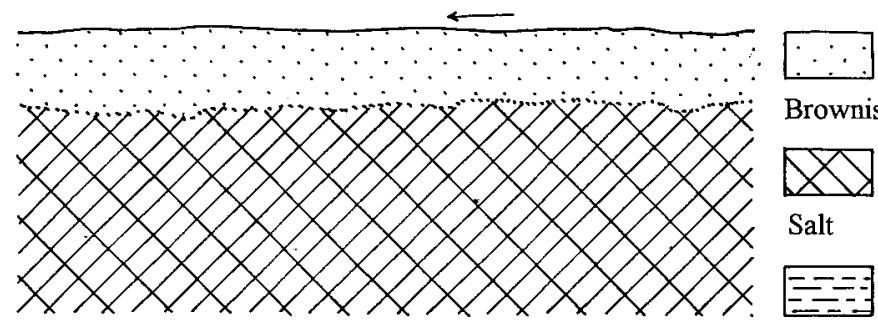

Brownish gypcrete

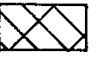

Salt
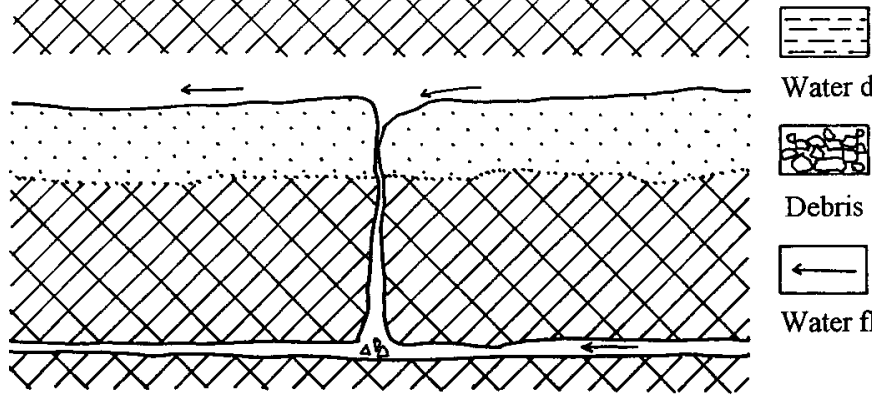

Water deposits

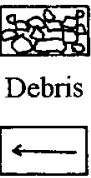

Water flow direction
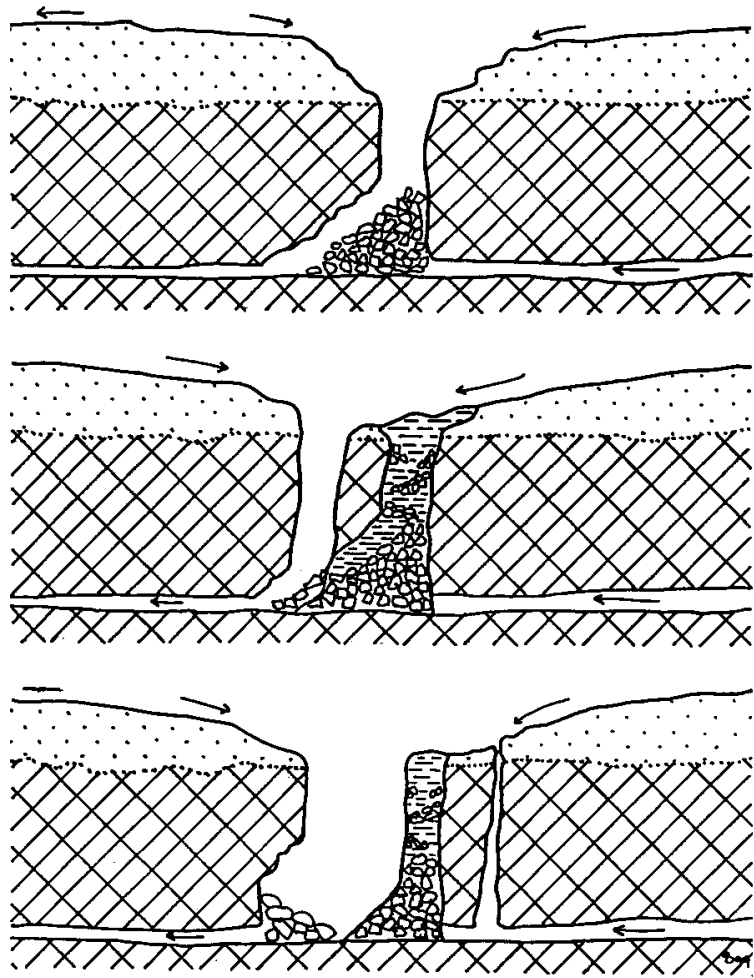

Fig. 10: The model of evolution of corrosion-collapse dolines (original J. Bruthans). 
springs of the Tarbu Anticline with a temperature of $60{ }^{\circ} \mathrm{C}$ must come from a depth of about $1,100 \mathrm{~m}$. Nevertheless, the depth of circulation can be lower as the water warming is influenced not only by the increased geothermal gradient in area with still active orogenic processes, but also by the activity of desulfurising bacteria, which produce large amounts of hydrogen sulphide, which is the common gaseous accompaniment of warm springs (Bosák et al 1998). The mixing of infiltrated waters (relatively cold precipitation) in dewatering branch with deep waters (warm often connate waters connected with oil reservoirs) affects the density of water circulating in the aquifer. These changes contribute to the activation of water circulation in the geohydrodynamical system. High temperatures of groundwater in flow openings indicate rapid ascent of water from the depth where it is warmed up to the surface.

\section{ACKNOWLEDGEMENTS}

The participants of speleological excursions acknowledge the services given by the Royal Dutch Airlines - KLM, Služby vypočetni technice Praha, and to the staff of IranoŠkoda Tehran. Some figures were drawn by Miroslav Morch (former Geoinduistria Praha) and by Josef Forman (Institute of Geology, ASCR, Praha, Czech Republic). The authors thank the Institute of Geology, Academy of Sciences of the Czech Republic in Praha for the permission to reprint figures 1, 2, 6 and 9.

\section{REFERENCES}

Bögli A., 1980. Karst Hydrology and Physical Speleology. - Springer Verl.: 1-284. BerlinHeidelberg-New York.

Bosák P., 1993. Karst Phenomena in the Bandar-e Khamir area, SE Iran. - Knih. Čes. speleol. spol., China Vol. 21. Praha.

Bosák P. Jaroš J., Spudil J., Sulovsky P., Václavek V., 1998. Salt Plugs in the Eastern Zagros, Iran: Results of Regional Geological Reconnaissance. - GeoLines, 7: 1-174. Inst. Geol. Acad. Sci. Cz. Rep. Praha.

Bosák P., Bruthans J., Fillippi M., Svoboda T., Šmíd J. (1999): Salt karst of the SE Zagros, Iran. Speleofórum'99: 41-46. Čes. speleol. spol. Praha.

Chabert C., Courbon P., 1997. Atlas de cavités non calcaires du monde. - Union Int. Spéléol. au prés Madame Carle: 1-120. Paris.

Ford D.C., 1977. Genetic classification of solutional cave systems. - Proceedings of the $7^{\text {th }}$ International Congress of Speleology: 189-192. Sheffield.

Ford D.C., Ewers R.O., 1978. The development of limestone cave systems in the dimensions of length and depth. - Can. J. Earth Sci., 15, 11: 1783-1798. Ottawa.

Ford D.C., Frumkin A., 1995. Rapid entrenchment of stream profiles in the salt caves of Mount Seldom. - Earth Processes and Landforms, 20: 139-152.

Frumkin A., 1982. Formation of potholes and caves in rock salt, Mount Sedom. - Niqrot Zurim, J. Israel Cave Res. Center, 6: 15-38.

Frumkin A. 1986. The cave survey of Mount Sedom, Israel. - Atti. Simp. Int. Carsisimo nelle Evaporite, Le Grotte d'Italia, 12: 305-308. 
Frumkin A., 1994a. Hydrology and denudation rates of halite karst. - J. Hydrol., 162: 171-189.

Frumkin, A. 1994b. Morphology and development of salt caves. - Natl. Speleol. Soc., Bull., 56: 8295. Huntsville.

Frumkin A., 1996a. Determining the Exposure Age of Karst Landscape. - Quaternary Res., 46: 99106.

Frumkin A., 1996b. Structure of northern Mount Seldom salt diapir from cave evidence and surface morphology. - J. Earth. Sci., 45: 73-80.

Frumkin A., 1996c. Uplift rate relative to base-levels of a salt diapir (Dead Sea Basin) as indicated by cave levels. - in Alsop G.I., Bundell D.J., Davidson I. (Eds.): Salt Tectonics. Geol. Soc. Spec. Publi., 100: 41-47.

Fürst M., 1970. Stratigraphie und Werdegang der östlichen Zagrosketten (Iran). - Erlangen Geol. Abh., 80, 1-51. Erlangen.

Fürst M., 1976. Tektonik und Diapirismus der östlichen Zagrosketten. - Z. dtsch. geol. Ges., 127, 183-225. Hannover.

Gansser A., 1960. Über Schlammvulkane und Salzdome. - Vjrschr. Naturforsch. Gesel. Zürich, 105, 1, 1-46. Zürich.

Harrison J.V., 1930. The geology of some salt plugs in Laristan (southern Persia). - Quart. J. Geol. Soc. London, 86, 4, 463-522. London.

Jenyon M.K., 1986. Salt Tectonics. - Elsevier Applied Sci. Publ., 1-191. London.

Kent P.E., 1958. Recent studies of south Persian salt plugs. - Amer. Assoc. Petrol. Geol. Bull., 42, 12, 2951-2979.

Kent P.E., 1970. The salt of the Persian Gulf region. - Trans. Leics. Lit. Philos. Soc., 64, 56-88. Leicester.

Kent P.E., 1979. The emergent Hormuz salt plugs of southern Iran. - J. Petrol. Geol., 2, 2, 117-144.

Lees G.M., 1927. Salzgletcher in Persien. - Mitt. Geol. Gesel. Wien, 20, 29-34. Wien.

Oberländer T., 1965. The Zagros streams. A new interpretation of transverse drainage in an orogenic zone. - Syracuse Geogr. Ser., 1, 1-168. New York.

Pilgrim G.E., 1908. The geology of the Persian Gulf and the adjoining portion of Persia and Arabia. - Mem. Geol. Surv. India, 34, 4, 1-177. Calcutta.

Samadian M.R., 1990. Evidence of late Cenozoic movements of the Zagros salt domes. - Proc. Symp. on Diapirism with Special Reference to Iran, Vol. 1, 324. Geol. Surv. Iran. Tehran.

Talbot J.C., Jarvis R.J., 1984. Age, budget and dynamics of an active salt extrusion in Iran. - J. struct. Geol., 6, 521-533.

Tavernier J.B., 1642. Les six voyages de Jean Baptiste Tavernier en Turquie, en Perse, et aux Indes. Pt. 1, livre 5. Paris.

Trusheim F., 1960. Mechanism of salt migration in Northern Germany. - Amer. Assoc. Petrol. Geol. Bull., 44, 1519-1540.

Trusheim T., 1974. Zur Tektogenese der Zagros-Ketten Süd-Irans. - Z. dtsch. geol. Ges., 125, 1, 119-150. Hannover.

Vita-Finzi C., 1979. Rate of Holocene folding in the coastal Zagros near Bandar Abbas, Iran. Nature (London), 278, 5705, 632-634. 
KRAS IN JAME V SOLNIH DIAPIRJIH JUGOVZHODNEGA ZAGROSA (IRAN)

\section{Povzetek}

Na področju Perzijskega zaliva je znanih okoli 200 solnih diapirjev. Predirajo do $12 \mathrm{~km}$ debelo skladovnico phanerozojskih sedimentov v nagubanem pasu gorovja Zagros. Mnogi diapirji so še aktivni in se kažejo kot prevladujoči vrhovi. Kraške kamnine predstavljajo kamena sol, redkeje sadra in anhidrid hormoškega kompleksa (od zgornjega proterozoika do srednjega kambrija), krovna kamnina in rjavkasti "gypcrete". Zadnji nastane kot posledica raztapljanja soli, je bolj ali manj strjen in lahko doseže debelino $10 \mathrm{~m}$.

Kraške oblike nastajajo največ v aktivnih, a tudi v "pasivnih" solnih diapirjih. V aktivnih so kraške oblike manjše in nekatere sploh niso razvite. Kras se razvija predvsem v ostankih uravnanih površij. V ostankih solnih diapirjev kraških oblik običajno ni, saj so bili sol in ostali evaporiti že prej raztopljeni. Kraške oblike so popolnoma primerljive z oblikami v "klasičnih" karbonatnih kamninah. Tako ločimo celo vrsto oblik: škraplje, valjaste "solution pipes", vrtače, korozijskoudorne vrtače (včasih z vodo na dnu), depresije podobne uvalam in poljem, slepe doline, soteskam podobne erozijske oblike, ponore, kraške izvire in jame. Tod sta bili odkriti in raziskani dve izmed najdaljših jam (tretja in peta po vrsti) v soli na svetu (Tří naháčů, 3160 m in Ghar-e Daneshyu, $1909 \mathrm{~m})$.

Daljše jame so nastale predvsem vzdolž gladine talne vode, včasih v 2-3 ravneh. Obsežnejše jame so bile odkrite v diapirjih blizu morske obale, vezane na morsko teraso $+20 \mathrm{~m}$. Jame so se razvijale v času ustaljene gladine talne vode. Pogosto predstavljajo zvezo zaprtih depresij, podobnih poljem, znotraj diapirja, z odtokom na robu diapirja in oziroma ali blizu obale. V dnu udornih vrtač in v ponorih so tudi strme, skoraj navpične in poševne (odtočne) jame.

Kraške procese predstavlja predvsem raztapljanje soli, redkeje sadre. Najpomembnejše je raztapljanje in odnašanja ("subrozija") halita izpod neprepustnega pokrova (gypcrete). V nekaterih diapirjih je dokazano globoko kroženje padavinske vode, ki često napaja globoke vodoprepustne vodonosnike v okoliških neevaporitnih phanerozojskih kamninah. 